$\begin{array}{cc}\text { Tür Coğrafya Dergisi } & \text { Turkish Geographical Review } \\ \text { Basıli ISSN 1302-5856 } & \text { ww.tcd.org.tr }\end{array}$

\title{
Kadın istihdamının coğrafyası ve bölgesel yakınsama
}

\section{The geography of women employment and regional convergence}

\author{
Suat Tuysuz *a (D) Kader Mutlu ${ }^{\mathrm{b}}$ \\ ${ }^{a}$ Erzincan Binali Yıldırım Üniversitesi, Fen-Edebiyat Fakültesi, Coğrafya Bölümü, Erzincan, Türkiye. \\ ${ }^{b}$ Erzincan Binali Yıldırım Üniversitesi, Sosyal Bilimler Enstitüsü, Coğrafya ABD, Erzincan, Türkiye.
}

ORCID: S.T. 0000-0002-6598-0746; K.M. 0000-0003-4711-3048

\section{BILGI / INFO}

Geliş/Received: 15.03.2021

Kabul/Accepted: 29.05.2021

\section{Anahtar Kelimeler:}

Kadın istihdamı

Bölgesel yakınsama

Bölgesel ıraksama

Kalkınma

\section{Keywords:}

Women employment

Regional convergence

Regional divergence

Development

\section{*Sorumlu yazar/Corresponding author:}

(S. Tuysuz) suattuysuz@gmail.com

DOI: $10.17211 /$ tcd.897597

\section{Atff/Citation:}

Tuysuz, S., \& Mutlu, K. (2021). Kadın istihdamının coğrafyası ve bölgesel yakınsama. Türk Coğrafya Dergisi, (77), 131-144. https://doi.org/10.17211/tcd.897597

\begin{abstract}
ÖZ / ABSTRACT
Geri kalmış bölgelerin kalkındırılması ve bölgelerarası gelir farklılıklarının azaltılması hususu hem dünyada hem de Türkiye'de uzun yıllardır tartısılmaktadır. Öyle ki bölgesel farklılıkların minimize edilmesi, bir kalkınmışlık göstergesi olarak kullanılmaktadır. Bölgelerin birbirinden farklılaşmasını sağlayan pek çok dinamik bulunmakla beraber bu çalışma, Türkiye'deki bölgesel farklılaşmayı eksik istihdam olgusu üzerinden ele alan bir çerçeveye sahiptir. Bir üretim faktörü olarak emeğin bir ülke ya da bölgede üretim sürecinde ol(a)madığı ya da kullanıl(a)madığı durum, eksik istihdam olarak tanımlanmaktadır. Buradan hareketle bölgelerin gelir durumu, mevcut potansiyelini kullanıp kullanamamasıyla da doğrudan ilişkilidir. Dolayısıyla bu çalışmada, kadının toplam istihdam içindeki oranı açısından bölgesel farklılaşmalar resmedilecek ve bu anlamda herhangi bir yakınsamanın olup olmadığı ortaya konulacaktır. Bu bağlamda, çalışmada 2008-2019 yıllarını kapsayan döneme ilişkin il bazındaki sigortalı sayıları kullanılmıştır. Analiz neticesinde Türkiye'de kadının toplam istihdam içerisindeki oranının istikrarlı bir biçimde arttğı görülmektedir. Ülke genelindeki istikrarlı artı̧, bazı bölgelerin yakınsama bazı bölgelerin ıraksama, bazı bölgelerin ise duraksama eğilimine girdiğini göstermektedir. Yakınsamanın hızlandırılması ve istikrarlı bir yapıya kavuşturulması, bölgesel ölçekte ve cinsiyet temelli politikaların uygulamaya konulmasıyla gerçekleşebilir. Bu da eksik istihdamın işgücüne katılarak ekonomik ilerlemenin sağlanması ve bölgesel farklılıkların azaltılması açısından önem arz etmektedir.
\end{abstract}

The development of lagging regions and the reduction of income differences between regions have been discussed both in the world and in Turkey for many years. So much so that minimizing regional differences is used as an indicator of development. This study has a framework that addresses regional differentiation in Turkey through the phenomenon of underemployment. A situation where labor is not in the production process in a region is defined as underemployment. In this sense, income level of regions is also directly related to whether they can use their current potential. In this study, regional differences in terms of the proportion of women in total employment will be illustrated and it will be revealed whether there is any convergence in this sense. In this regard, we used the insured numbers for the period covering 2008-2019. As a result of the analysis, it is found that the proportion of women employment in Turkey is rising steadily. The steady rising give rise to that certain regions tend to converge, some regions diverge, and some regions stable. Accelerating convergence can occur based on regional and gender-based policies. This, in turn, is important in terms of ensuring economic progress and reducing regional differences.

\section{Extended Abstract Introduction}

The development of lagging regions in Turkey and the reduction of income differences between the regions have been discussed both in policy documents and research articles for many years. Although there have been various efforts on this issue since the proclamation of the Republic, the reduction of regional income differences has not yet reached a sufficient level in Turkey. Although there are many efforts to eliminate interregional differences, various studies addressing convergence show that absolute regional convergence could not occur (Gezici \& Hewings, 2004; Halaç \& Kuştepeli, 2008; Abdioğlu \& Uysal, 2013; Karaca, 2018). Although there is no outcome about absolute convergence in the regional sense in Turkey, there are findings that show that conditional convergence 
occurs (Filiztekin, 1998). After the 2000s, regional differences tend to relative converge to previous periods (Karahasan \& Bilgel, 2018). From this point of view, the current level of regional differences in Turkey indicate ineffectiveness of the policies implemented so far (Karahasan \& Bilgel, 2018).

An increase in the income of a region occurs through the effective and efficient use of factors of production such as land (natural resources), labor, capital, entrepreneur and technology. Effective and efficient use of factors of production is a dynamic that can reduce regional differences. Insufficient use of labor resources is defined as underemployment (Taşçı \& Darıcı, 2010). Therefore, the issue that created regional inequalities in this study was associated with female employment, which can be define as one of the factors of production. In almost every region of Turkey, male and female population rates are almost equal to each other, while there is a huge differences in women labor force participation rates. Indeed, the active inclusion of women employment in the economic process is essential for both accelerating development and sustainable development (Karabıyık, 2012; Özdemir et al., 2012). Women's participation in economic life does not only strengthens their economic strength, but also strengthens their social role (Bacchus, 2005). As can be seen from World Bank reports, countries experiencing gender-based discrimination experience deeper poverty, slow economic growth, weak governance and low living standards (Doğan \& Mehmet, 2014).

In this vein, the present study has a framework that addresses participation of women employment based on regional differentiation in Turkey through the phenomenon of underemployment.

\section{Data and Method}

Therefore, in this study, regional differences in terms of the proportion of women in total employment will be illustrated and it will be revealed whether there is any convergence in this sense in the NUTS 3 level in Turkey. For this, we used the number of insured based on NUTS 3 level for the period covering the years 2008-2019. In convergence studies, standard deviation values are used as an important indicator. Therefo$\mathrm{re}$, in this study, convergence interpretations will be made based on standard deviation values. From this point of view, the standard deviation's tendency to decrease over time is described as convergence, and its increasing tendency as divergence (Sevinç et al., 2016). In other words, the decreases in the standard deviation values by years indicate that the regions converge to each other, that is, the regional differences tend to decrease, and the increases in the standard deviation values indicate that the regions diverge, that is, the differentiation between the regions increases.

\section{Result and Discussion}

The findings reveal that both female employment and male employment show a steady increase in Turkey general. The increase between these years was 330\% in women and $240 \%$ in men (see Figure 1). Although women employment is greater than men's, there is still a large differentiation on a more regional scale. For example, in some regions, the proportion of women in total employment is $8.5 \%$, while in some regions it is $35.5 \%$ (see Figure 2 and Appendix 1 for this). In the years referenced, oscillations in standard deviation values are observed (Table 1). The dates when the standard deviation values are low mean the years when the convergence occurs, and the dates when it is high mean the years when the divergence occurs.

When the twelve-year period covering 2008-2019 is divided into three-year periods, the period in which the average standard deviation is minimal occurs in the period covering 20142016. Therefore, this period stands out as the period in which regional convergence occurs the most in Turkey (Table 1). When we look at that where the convergence and divergence occurs, we see the Figure 3 which referes standart deviations by NUTS 3 level. The dark blue and light blue provinces in Figure 3 show the regions where convergence occurs. Figure 3 shows convergence is generally observed to occur on the northern coastline and inland regions of Turkey. Ardahan and Hakkari where is located the east part of Turkey are the most divergent group of provinces (Figure 3, dark brown provinces).

\section{Giriş}

Geri kalmış bölgelerin ${ }^{1}$ kalkındırılması ve bölgelerarası gelir farklılıklarının azaltılması hususu hem dünyada hem de Türkiye'de uzun yıllardır tartş̧ımaktadır. Türkiye'de geri kalmış bölgelerin kalkındırılması ve bölgesel farklılıkların azaltılmasına yönelik ilk hamlelerin 1933-1936 yıllarını kapsayan Birinci Sanayi Planı'ndan itibaren yapıldığı söylenebilir. Zira, Birinci Sanayi Planı'nda, kamu sanayi kuruluşlarının yer seçimi Anadolu sathına yayılacak türden bir örüntü göstermekteydi ki bu da bölgesel eşitsizliği azaltmaya yönelik bir hamle olarak değerlendirilebilir (Yavan, 2011). Cumhuriyet'in ilk yıllarında devlet yatırımlarının yurt sathına yayılmış olması, bölgesel farklılıkları ortadan kaldırmaya katkı sunacak bir yapı gösterse de, Özaslan’a (2006) göre 1920-1960 arasını kapsayan dönemin önceliği, bölgeselden ziyade ulusal kalkınmadır. Dolayısıyla kimi araştırmacılar bu dönemdeki kamu sanayi kuruluşlarına ilişkin yer seçim kararlarının bölgesel eşitsizliği azaltmaktan ziyade hammadde ve güvenlik kaygısıyla şekillendiği kanısındadır (Özaslan, 2006). Ancak Ataay'ın da (2001) belirttiği üzere kamu sanayi kuruluşlarının yer seçiminde hammaddeye, pazara veya sanayi kuruluşlarına yakınlığın yanı sıra yerel sermayenin ve taşra siyasetinin baskıları da Anadolu kentlerini kamu yatırımına sahip kılmıştır (Ataay, 2001). Benzer şekilde Mutluer (1999) de özel sektörün daha çok İstanbul, Ankara ve İzmir gibi ülkenin batısında yoğunlaştı̆ını buna karşın devlet işletmelerinin yurdun geneline yayıldığını belirtmiştir. Dolayısıyla sanayinin ülke sathına dağılımında KiT’ler (Kamu İktisadi Teşekkülleri) oldukça önemli bir rol üstlenmişlerdir (Ataay, 2001). Gerçekten de yerel dinamiklerle sanayileşemeyen veya büyük sermaye tarafindan cazip olarak bulunmayan iller, kamu yatırımları yoluyla desteklenmişlerdir. Dolayısıyla KiT’lerin hem geri kalmış bölgeler açısından hem de ülke genelindeki eşitsizliklerin azal-

\footnotetext{
1 Makale boyunca kullanılacak olan bölge kavramı kimi durumlarda iBBS kapsamındaki düzey 3 bölgelerini (illeri) ifade etmek amacıyla kullanılmışken baz cümlelerde illerden daha büyük alanı ifade etmek amacıyla doğu bölgesi, bat bölgesi şeklinde kullanılmıştır. Dolayısıyla metin okunurken bu durum dikkate alınmalıdır.
} 
tılması açısından önemli bir misyon üstlendikleri belirtilmektedir (Ataay, 2001). Eşiyok'un (2012) da ifade ettiği üzere özellikle neoliberal politikaların uygulamaya konulduğu 1980'lerden önce, devletin üretici bir aktör olarak iktisadi faaliyetlerde bulunmasının bölgesel eşitsizlikleri giderici bir yönü vardır. Buradaki bilgilerden hareketle kamu sanayi kuruluşlarının Anadolu sathına yayılmasının gerekçesi ister hammaddeye veya pazara yakınlığa isterse de güvenlik ya da yereldeki siyaseti tatmin etmeye yönelik popülist bir tavra dayansın nihayetinde bölgesel eşitsizlikleri azaltıcı bir rol üstlendiği muhakkaktır.

1960'lardaki planlı döneme geçinceye kadar hazırlanan politika belgelerinde bölgesel eşitsizliklerin giderilmesine yönelik açık bir vurgu olmasa da yapılan hamleler yukarıda da belirtildiği üzere sanayileşmenin ülke sathına yayılması yoluyla bölgesel eşitsizlikleri azaltmaya yönelik bir politikanın uygulandığına işaret etmektedir. 1963 sonrası hazırlanan beş yıllık kalkınma planlarında ise bölgesel gelişme hususu, açık bir biçimde önemli bir gündem maddesi olarak yer edinmeye başlamıştır. Buna yönelik olarak 1960'ların sonlarında teşviklerden az gelişmiş bölgelerin daha fazla faydalandırılması ön plana çıkmıştır. Bu kapsamda, 1968 yılında getirilen Kalkınmada Öncelikli Yöreler (KÖY) uygulamasıyla bölgesel kalkınmaya ve bu sayede bölgesel gelir farklılıklarının giderilmesine yönelik vurgu artmaya başlamıştır (Yavan, 2011).

1980'lerdeki ihracata dayalı kalkınma hamlesi, bölgeselden ziyade ulusal kalkınma modelini yeniden ön plana geçirmiştir. Her ne kadar böyle olsa da 1989 yılında kurulan GAP Projesi Bölge Kalkınma İdaresi'nin bölgesel eşitsizliklerin giderilmesine yönelik önemli bir hamle olduğunu da vurgulamak gerekir. Öyle ki söz konusu proje, 2011 yılında kurulacak olan DAP, DOKAP ve KOP gibi kalkınma idarelerine de rol model oluşturmuştur (Akpınar, 2017). 1999 yılında Türkiye'ye Avrupa Birliği'ne $(A B)$ adaylık statüsü verildikten sonra ise kalkınma politikasında yeniden bölgesel ölçek ön plana çıkmaya başlamıştır. Çünkü adaylık statüsü veren $A B^{\prime}$ nin bölgesel politikalarındaki temel gaye, geri kalmış bölgelerin kalkınmasına destek olmak ve bölgeler arası dengesizlikleri azaltmaktır (TÜsiAD, 2008). Bu çerçevede hem kalkınma ajansları üzerinden yereldeki dinamiklerin harekete geçirilebileceği bölgesel politikalar üretilmeye başlanmış, hem de DOKAP, DAP, KOP (Akpınar, 2017; Yavan, 2011) gibi bölgesel projeler aracılığıyla bölgesel eşitsizliklerin giderilmesi hedeflenmiştir.

Türkiye'de bölgesel farklılıkların azaltılmasına yönelik yukarıda anlatılan pek çok çaba olsa da, yapılan çalışmalar mutlak bir bölgesel yakınsamanın gerçekleşemediğini (Gezici \& Hewings, 2004; Halaç \& Kuştepeli, 2008; Abdioğlu \& Uysal, 2013; Karaca, 2018) ortaya koymaktadır. Bölgesel farklılıkları azaltmaya yönelik politikalarla uyumlu olacak şekilde 2009 yılında getirilen yeni teşvik sistemiyle ise ilk defa kapsamlı sektörel-bölgesel teşvik sistemi uygulanmıştır. 2009 yılında uygulamaya konulan Yeni Teşvik Sistemi'nde Türkiye, SEGE'ye göre dört bölgeye ayrılarak teşvik yoğunlukları bölgelerin gelişmişlik seviyesine göre belirlenmiştir (Yavan, 2011). 2012 yılında yapılan düzenlemeyle ise bölge sayısı dörtten altiya çıkarılmıştır (Demirli, 2015; Takım \& Ersundur, 2018). Dolayısıyla 2009 yılında başlatılan ve 2012 yılında revize edilen söz konusu sistemde illerin gelişmişlik durumu göz önüne alınarak bölgesel gelişmişlik farkının azaltılması hedeflenmiştir. Ancak yapılan araştırmalar teşvik sisteminden gelişmiş bölgelerin daha fazla faydalandığını ortaya koymaktadır (Yavan, 2012). Bölgelerin yakınsamasını ortaya koymaya yönelik yapılan araştırmalarda mutlak bir yakınsamadan bahsedilemese de koşullu bir yakınsamadan bahsetmek mümkündür (Filiztekin, 1998; Doğruel ve Doğruel, 2003). Özellikle 2000'li yıllardan sonra bölgesel farklılıkların önceki dönemlere göre göreli olarak bir yakınsama eğilimine girdiği belirtilmektedir (Karahasan \& Bilgel, 2018). Ancak yine de bölgesel farklılıkların mevcut düzeyi, uygulanan politikaların etkisizliğine işaret etmektedir (Karahasan \& Bilgel, 2018).

Bölgeler arası gelir farklılıklarını artıran husus, kuşkusuz bir bölgenin üretim faktörleri üzerinden şekillenmektedir. Zira, bir bölgenin gelirinin artması; toprak (doğal kaynak), emek, sermaye, girişimci ve teknoloji gibi üretim faktörlerinin etkin ve verimli bir şekilde kullanılmasıyla gerçekleşmektedir. Üretim faktörlerinden biri olarak emeğin bir ülke ya da bölgede üretim sürecinde ol(a)madığı ya da kullanıl(a)madığı durum, yani işgücü kaynağının yeterince kullanılamaması eksik istihdam olarak tanımlanmaktadır (Taşçı \& Darıcı, 2010). Öyle ki, eksik istihdam gibi bir durumun olması, diğer üretim faktörlerinin de tam kapasiteyle çalışma imkanını kısıtlamakta, bununla ilişkili olarak da düşük çıktıya ve sosyal refahta kayba neden olmaktadır (Rutkowski, 2006). Düşük çıkt ve sosyal refah kaybındaki daralma ise bumerang etkisi yaratarak istihdamın genişlemesini de geriletecek türden bir sarmala neden olmaktadır (Berberoğlu, 1996). Gerçekten de kadın istihdamının ekonomik sürece aktif bir biçimde dahil edilmesi, hem kalkınmanın ${ }^{2}$ hızlandırılması hem de dengeli bir büyüme sağlayacak olmasından ötürü kalkınmanın sürdürülebilir kılınmaSı açısından önemlidir (Karabıyık, 2012; Özdemir vd., 2012). Dolayısıyla kadın istihdamının artırılması bölgelerin gelirinde artş sağlayarak bölgesel dengesizliklerin giderilmesine katkı sunacaktır. Kadınların ekonomik yaşama katılmaları, yalnızca ekonomik olarak güçlenmelerini sağlamamakta aynı zamanda toplumsal rollerini de güçlendirmektedir (Bacchus, 2005). Söz konusu kazanımlar feminist literatürde bilinç yükseltmesi olarak tanımlanmaktadır (Donovan, 2015). Bu tanımlama, kadının istihdama katılımına ekonomik getirilerin ötesinde bir anlam yüklemektedir. Kadınların toplumsal rollerinde meydana gelen güçlenme hem bireysel gelişmenin hem de sürdürülebilir bir toplumsal kalkınmanın sağlanması açısından önemlidir (Karabıyık, 2012). ${ }^{3}$ Gerçekten de kadının işgücünde yer al(a) maması yalnızca bir istihdam sorunu değildir. Bu durum kadına yönelik şiddet, gelir dağılımı adaletsizliği, karar alma mekanizmalarından uzaklaşılması, eğitim ve sağlık imkânlarından yoksun kalınması gibi pek çok soruna da dayanak teşkil etmektedir (Koray, 2008; Yumuş, 2011). Dolayısıyla kadın istihdamının artirılması sosyal göstergeler açısından da bölgelerin farklılığını azaltacak türden bir etki yaratacaktır. Dünya Bankası'nın raporlarından da izlenebileceği üzere cinsiyet temelli ayrımcı-

2 Ferhunde Özbay, Boserup’a dayandırarak Afrika örneği üzerinden ekonomik kalkınmanın kadınların durumlarını ileriye götürmediğini hatta gerilettiğini belirtmiştir (Özbay, 2019).

3 Öyle ki On Birinci Kalkınma Planı’nın Kadının Kalkınmadaki Rolü başlıklı Özel ìhtisas Komisyonu Raporu’nda da kalkınma hamlesinin sürdürülebilirliğini sağlayabilmek için kadının toplumdaki rolünü güçlendiren politikaların temel alınması gerektiği vurgulanmaktadır. 
Iığın yaşandığı ülkelerde daha derin bir yoksulluk, daha yavaş bir ekonomik büyüme, güçsüz bir yönetişim yapısı ve düşük yaşam standartları gözlenmektedir (Doğan \& Mehmet, 2014).

Ancak belirtmek gerekir ki, istihdam açısından cinsiyet temelli eşitsizlik, derecesi farklılaşmakla beraber neredeyse bütün ülkelerde gözlenen bir gerçekliktir. Dünya Bankası verilerine göre 2020 yılında dünyada kadının işgücüne katılımının en az olduğu ülke, \%5.7 ile Yemen'dir. Onu \%11.8 ile Irak, \%14 ile ise Suriye izlemektedir. Arap dünyasında bu oran \%20.8, Avrupa Birliği'nde (AB) \%50.5, Ekonomik İşbirliği ve Kalkınma Örgütü (OECD) ortalaması \%52, Almanya'da \%55.3, ABD'de \%55.9, Bileşik Krallık'ta \%57.7, Çin'de \%59.8, Güney Kore'de ise \%73.3 şeklindedir. Dünya ortalaması \%46.9, Türkiye'de ise bu oran \%33.9 şeklindedir (Dünya Bankası). Burada dikkat çeken husus, ekonomik gelişmişlik arttıç̧a kadının işgücüne katılımının da artmasıdır. Ancak kadınların işgücüne katılımının gelişmiş ülkelerden bile yüksek olduğu bazı ülkelerin dünyanın en geri kalmış ülkeler olduğu gerçeğini de gözden kaçırmamak gerekir (örn. 2020 yılı verilerine göre Ruanda'da bu oran \%83.9'dur. Bu yönüyle Ruanda, kadının istihdama katılımın en yüksek olduğu ülkedir). Dünyanın en geri kalmış ülkelerinde kadınların işgücüne kathlımının çok yüksek oranlarda gerçekleşmesi, söz konusu ülkelerin ekonomik faaliyetleriyle ilişkilidir. Bu durum, Gerşil (2015) tarafindan da belirtildiği üzere, kadın işgücü arzının kalkınma süreci boyunca izlediği yolun, "U" şeklinde bir çizgisellik göstermesiyle ilişkilidir. Tarımsal faaliyetlerin baskın olduğu ülkelerde kadının tarımsal faaliyetlerde yoğun biçimde çalışması, kadının işgücüne katılım oranlarını yükselten yegane unsurdur. Sanayileşme ve kent nüfusunun artışıyla kadın işgücü arzının azalacağı, sanayileşmenin ve kentleşmenin olgunlaşmasıyla birlikte ise kadınların işgücüne katılımının artş̧a geçeceği öngörülmektedir (Gerşil, 2015). Dolayısıyla dünyanın en geri kalmış ülkelerinin kimilerinde gelişmiş ülkelerin de üzerinde görülen yüksek katlım, geri kalmış ülkelerin ekonomik faaliyet türleriyle ilişkilidir.

Kadın istihdamının ekonomiye sağladığı katkıya tekrar dönülecek olunursa, yapılan hesaplamalarda, Türkiye'de kadının işgücüne katılımının \%38'ye yükselmesi kişi başına geliri tahmini 19 bin dolara, katlımın \%61'e yükselmesi ise kişi başına geliri 21 bin dolara çıkaracaktır (Aşık, 2013). Bu bağlamda, kimi araştırma merkezleri tarafindan yapılan çalışmalarda da, Türkiye'yi ekonomik açıdan kısır döngüden kurtaracak çözümün, kadının işgücüne katılımıyla sağlanacağı vurgulanmaktadır (Serel \& Özdemir, 2017).

Türkiye'de kadının istihdama katılımı Dünya Bankası verilerine göre 2020 yılında \%33.9 gibi düşük bir oranla halen daha gelişmiş ülkelerin oldukça altında olsa da son yıllarda önemli bir artış yaşandığını da kaydetmek gerekir. Bu çalışmada sorunsallaştırılan husus ise söz konusu oranın bölgesel olarak derin bir farklılaşma göstermesidir. Kadının istihdam içerisindeki oranının bölgesel olarak farklılaşması, bölgesel gelir farklılığını da yaratan bir dinamik olarak belirmektedir. Bu bilgilerden hareketle, bu çalışmanın iki amacı bulunmaktadır. Birincisi, toplam istihdam içerisinde kadınların oranını bölgeselleştirmek; ikincisi ise kadının toplam istihdam içerisindeki oranının hangi bölgelerde yakınsama hangi bölgelerde ise ıraksama gösterdiğini ortaya koymaktır. Bu sayede, üretim faktörlerinden biri olan emek faktörünün hem bölgesel olarak etkin kullanımına ilişkin mekânsal örüntü hem de bu etkinliğin yakınsama veya ıraksamaya ilişkin örüntüsü anlaşılmış olacaktır. Bilindiği üzere yakınsama olgusu neoklasik iktisattaki önemli yaklaşımlardan biridir. Söz konusu model, ülkeler ve bölgeler arasındaki farklılıkların zamanla ortadan kalkacağına yani geri kalmış olan bölgelerin zamanla gelişmiş bölgeleri yakalayacağına dayalıdır (Baypınar \& Erkut, 2011; TÜSIAD, 2008; Gezici \& Hewings, 2004; Karahasan \& Bilgel, 2018; Nas \& Değirmen, 2018). Bu husus, yakalama olgusu olarak da ifade edilmektedir (Nas \& Değirmen, 2018). Bölgesel yakınsamayı üretkenlik farklılığı (Baypınar \& Erkut, 2011) kişi başına GSYiH (Gezici \& Hewings, 2004; Karaca, 2018; Karahasan \& Bilgel, 2018), kişi başına katma değer (TÜSIAD, 2008) verileri üzerinden ele alan çalışmalardan farklı olarak bu araştırma, bölgesel farklılıkları cinsiyet temelli eksik istihdam olgusuna dayandırarak ele almaktadır. Bu yönüyle bahsedilen çalışmalardan farklılaşmaktadır.

\section{Kadının İstihdama Katılımına İlişkin Arka Plan Bilgisi}

Kadınların işgücüne katılımı açısından ülkeler arasındaki farklılaşmalar ciddi düzeylerdedir. Farklılaşmayı yaratan husus; ekonomik, kültürel veya politik olarak farklı başlıklar altında ele alınabilir. Ekonomik nedenler; daha çok kadının işgücü piyasasında kazandığı ücret düzeyiyle ilişkilidir (Walby, 2021). Gerçekten de işgücündeki bir kadının kazancı; çocuk bakımı, ev işleri, yol masrafi, sosyal ihtiyaçların artması vb. gibi işgücüne katılımdan ötürü doğacak ekstra maliyetleri karşılamaması durumunda kadının işgücüne katılmaktan vazgeçebileceği ifade edilmektedir (Gerşil, 2015). Yani, dışarıdan satın alındığında ortaya çıkacak olan maliyet, kadının çalışması durumunda elde edebileceği kazanca eşit veya yakınsa, bu durum kadının işgücüne katılmamasıyla sonuçlanmaktadır. Dolayısıyla bu husus, kadının istihdama katıl(a)mamasının ekonomik nedeni olarak gösterilmektedir (Gerşil, 2015). Bu durum evde kalmanın firsat maliyeti olarak da ifade edilmektedir (Ercan \& Özar, 2000). İstihdama katımamanın kadın açısından firsat maliyeti olarak değerlendirilmesi, kadının işgücü piyasasında düşük ücretle çalıştırılmasıyla doğrudan ilişkilidir. Marksist perspektifte, düşük ücretle çalışmaya rıza göstermelerinden ötürü kadınların sermaye açısından yararlı bulundukları (Omay, 2011) belirtilse de, bu durum kadının işgücüne katılımının düşüklüğüne ilişkin bir açıklama getirememektedir (Koca, 2016). Bir diğer ifadeyle, kadınların işgücü piyasasında fazlaca yer alması, sermaye sahiplerinin karını maksimize edebileceği bir ortama olanak tanısa da kadınların piyasadaki görünürlüklerinin buna rağmen zayıf olması, Marksist perspektifin bu noktadaki açıklama gücünün zayıflığına işaret etmektedir (Walby, 2021). Marksist perspektifte istihdam piyasasında kadınların görünürlüğünün az olmasına yönelik getirilen açıklama, kadın emeğinin ucuz olmasıyla ilişkilidir. Nitekim, kadınların piyasada düşük nitelikteki işlerde çalıştırılmaları kadınların işgücü piyasasından uzaklaşmasının gerekçesi olarak sunulmaktadır (Walby, 2021). Benzer şekilde Marksist perspektifte kadınlar yedek işgücü ordusu olarak da tanımlanmaktadır. Özellikle işgücüne olan talebin arttğı dönemlerde işçi ücretlerindeki artşı engellemek adına sermayenin kadınları işgücü piyasasına dahil ettikleri belirtilir (Walby, 2021). Dolayısıyla bu durumda da kadın, emek piyasasındaki ücret artışını engellemek amacıyla 'araçsallaştrıımaktadır'. Bu da istihdama dahil ediliyor gibi gözükse de kadına dezavantajlı bir rol yüklendiğinin göstergesidir. 
Kadının işgücüne katılımını belirleyen bir diğer faktör, kültürel ve politik dinamikler üzerinden şekillenmektedir. İstihdama katılımı açıklamaya yönelik kültürel faktörler; toplum tarafindan inşa edilmiş cinsiyet rolleri, toplumun çalışan kadına karşı bakışı, kadının işyerinde maruz kaldığı fiziksel, psikolojik ve cinsel şiddetle alakalı pek çok etkeni içerirken (Çakır, 2008; İnce, 2010; Karakuş, 2014, Walby, 2021), politik faktörler devletin rolü ve toplumdaki güç ilişkileri üzerinden şekillenmektedir (Walby, 2021). Nitekim, birinci dalga Feminizm olarak ifade edilen 1850 'lerden 1930 'lara kadar geçen sürede kadınların Ingiltere'de politik vatandaşılık hakkı (oy hakkı ${ }^{4}$ ), eğitim hakkı, meslek sahibi olma hakkı ve mülkiyet edinme haklarında elde ettikleri kazanımlar devletin kadınlara karşı tutumunda bir takım değişimleri de beraberinde getirmiştir (Walby, 2021). Kadınların oy hakkını elde etmesiyle beraber politik alanda elde edilen kazanım, önceden kadınların istihdamdaki bazı haklarını sınırlandıran devlet aygıtının kadınlara karşı tutumunu değiştirmesini sağlamıştır. Bu haklar sayesinde kadınların ücretli emeğe katılımı artış göstermiştir (Walby, 2021).

Kadının işgücüne katılımının pek çok çabaya rağmen sınırlı olması, cam tavan sendromu ${ }^{5}$ olarak ifade edilmektedir. Hem ekonomik, hem kültürel hem de politik dinamikler, kadının istihdam piyasasındaki görünürlüğünü kısıtlayan fiili bir durum ortaya çıkarmaktadır. Kadının işgücüne katılımını sınırlandıran bu türden faktörler Diana Pearce'nin kavramsallaştırmasıyla söylenecek olunursa yoksulluğun kadınlaşması (Pearce, 1978'den aktaran McLanahan ve Kelly, 2006) gibi bir sonucu da beraberinde getirmektedir.

Yukarıda bahsedilen ekonomik, kültürel ve politik faktörler mekana duyarsız değildir. Yani, söz konusu faktörler, dünyanın farklı bölgelerinde veya aynı ülke sınırları içindeki farklı bölgelerde değişik bir görünüm sergileyebilmektedir. Ancak yine de en gelişmişinden en geri kalmışına kadar kadın, hemen her toplumda annelik üzerine konumlandırımakta, bu da kadının işgücü piyasasındaki görünürlüğünü zayıflatmaktadır. Öte yandan Yüceşahin (2016), kadına yüklenen 'narinlik' rolünün de kadını eve kapatma mekanizması olarak işlediğini ifade etmektedir. Kadına toplumda atfedilen bu rol, onu gündelik hayatta çocuk bakımı, temizlik ve beslenme gibi ev işlerine yönelik faaliyetlerin yürütülmesi anlamında özel alanla sınırlandırmakta (Dedeoğlu, 2000) bu da ekonomiye katkısının sınırlı olmasına neden olmaktadır. Kuşkusuz burada belirtilmesi gereken en önemli hususlardan biri de özellikle kırsaldaki kadınların ekonomik faaliyet içerisinde yer alsa dahi bunun ev işinin bir uzantısı olarak görülüp kayıt dışı olarak gerçekleşmesi ve kadın emeğiyle elde edilen gelirin kadınların kendi kontrolünün dışında olmasıdır (Cihangir vd., 2020). Bu da üretim sürecinde yer alsa dahi kadının görünürlüğünün ve toplumsal yaşama katılımının yeterince olamamasına neden olmaktadır (Cihangir vd., 2020).

\section{Dünyada ve Türkiye'de Kadın İstihdamının Tarihsel Seyri ve Önemli Kırılma Noktaları}

Kadınların işgücü piyasasında ücretli olarak yer edinmelerine yönelik tarihsel birkaç kırılma noktasından bahsedilebilir. Bilindiği üzere, Sanayi Devrimi öncesinde kadınlar, yaşadıkları dönemin özelliğine göre köle, serf gibi farklı konumlarda işgücü piyasasında yer almışlardır (Koca, 2016). İngiltere, Almanya ve Fransa gibi ülkelerin başını çektiği sanayileşmiş ülkelerde, kadın istihdamını artırmaya yönelik uygulamalara 18. yüzyılın sonlarından itibaren başlanmış olmasına rağmen bu uygulamalar, dönemin ağır sanayi yapısından ötürü istenilen düzeyde gerçekleşememiştir. Zira, daha çok kas kuvvetine dayalı olan bir sektörde kadın istihdamını arttrmak reel anlamda arzu edilen bir durum olarak görülmemiştir (Sevinç vd., 2016). Ancak görece daha hafif bir sanayii temsil eden tekstil sanayinde yaşanan gelişmeler, kadının işgücüne ücretli olarak katılımını sağlayan ilk ve önemli bir kırılma noktası olmuştur. Öyle ki, Sanayi Devrimi'nin ortaya çıktı̆ı İngiltere'de 1851 yılında kadınların istihdam içindeki oranı \%45 düzeyine ulaşmıştır (Peker \& Kubar, 2012).

19. yüzyılın sonlarına doğru sanayideki ağırlığın tekstilden metalürji ve otomotiv gibi sektörlere kayması, kadın işgücünün nisbi düşüşüyle sonuçlanmıştir (Doğan \& Mehmet, 2014). Ancak bir süre sonra, söz konusu sektörlerin kentlerde yarattı̆ı hareketlilik, kadınların hizmet sektöründe özellikle temizlikçi olarak çalışmaya başlamalarıyla emek piyasasındaki görünürlüklerinin artmasını sağlamıştır (Peker \& Kubar, 2012). Yıllar ilerledikçe kadın istihdamına ilişkin artı̧̧, İngiltere dışında Fransa ve Almanya gibi diğer Avrupa ülkelerinde de görülmeye başlanmıştır. Kadınlar her ne kadar işgücünde görünürlüklerini artırarak niceliksel olarak önemli bir varlık gösterseler de ücretler açısından aynı etkiyi yaratamamışlardır. Nitekim 1900'lü yıllarda kadınların aldığı ücret, erkeklerin aldığı ücretin yarısı kadardı. Bu ücret düzeyi ancak tekstil gibi sektörlerde erkeklerin aldığı ücretin üçte ikisine çıkabiliyordu. Bu durum, erkeklerin işten çıkarılması gibi erkek aleyhine fiili bir duruma da yol açabilecek mahiyetteydi. 1930'larda eşit ücret politikasının uygulamaya konulması, kadınlar için ücret artışı, erkekler için ise işteki pozisyonlarını koruma anlamına gelmekteydi. Çünkü kadının aynı işte erkeğe nazaran daha az ücretle çalışması erkeğin işten çıkarılması gibi travmatik olarak sonuçlanabilecek bir potansiyele sahipti (Peker \& Kubar, 2012).

Kadınların çalışma hayatında görünürlüklerinin artması, belli bir süre sonra çeşitli hakları elde etmelerine yol açmıştır. Bu bağlamda cinsiyet ayrımına yönelik yasalar çıkarılmıştır. Sanayileşmenin beşiği İngiltere'de görülen bu türden gelişmeler dünyanın diğer ülkelerine de yayılmış ve kadınlar; eşit ücret, doğum, çocuk bakımı, sosyal güvenlik hakkı gibi konularda çeşitli hakları kazanmışlardır (Peker \& Kubar, 2012). Özlük haklarına ilişkin olarak elde edilen kazanımlar, kadının çalışma hayatındaki görünürlüğünü artıran bir diğer faktör olmuştur. Kadınların savaş dönemlerinde rezerv işgücü olarak görülmesinden dolayı işgücü piyasasına dahil edilmeleri, kadınların işgücü piyasasındaki görünürlükleri artıran ikinci bir kırılma noktası yaratmıştır. II. Dünya Savaşı sırasında İngiltere'de kadın istihdamını artır-

\footnotetext{
4 İngiltere'de kadınların ilk defa oy hakkını elde etmeleri 1918 ve 1928 yılındaki düzenlemelerle gerçekleşmiştir. 1918 yılında yalnızca 30 yaş üstünde olup evli ve bir miktar mülk sahibi olan kadınlar oy hakkını elde etmişken, 1928'de bu hak tüm kadınları kapsayacak şekilde genişletilmiştir (Walby, 2021).

5 Cam tavan sendromu, kadınların eğitim, başarı gibi tüm şartlara haiz olmalarına rağmen görünmeyen ancak aynı zamanda geçilemeyen bir engeli ifade etmek için kullanılan bir tanımlamadır. Kavram ilk olarak 1986 yılında "glass ceiling" olarak Wall Street Journal gazetesi tarafindan kullanılmıştır (Önder, 2013, s. 53).
} 
maya yönelik olarak verilen teşvikler bunun bir örneğidir. Savaş döneminde işgücüne katılan kadınlar savaş bitince işgücü piyasasından çekilmemişlerdir. Dolayısıyla Sanayi Devrimi'nde tekstil sanayindeki artışa bağlı olarak gerçekleşen ilk kırılma noktasını II. Dünya Savaşı'ndan kaynaklanan ikinci kırılma noktası izlemektedir (Peker \& Kubar, 2012). Söz konusu kırılma noktası, kadın istihdamını artırmakla beraber, kadınların yeni haklar elde etmesine de yol açmıştir. 1960'lar ve 70'ler feminist hareketlerin de yükselişe geçmesiyle kadınların haklarını genişlettiği yıllara denk gelmektedir. Örneğin, 1968 yılında, eşit ücret mücadelesi ivme kazanmış, 1975 yılına gelindiğinde "Cinsiyet Ayrımı Karşıtt" yasa İngiliz İşçi Hükümeti tarafindan kabul edilmiş ve bu yasa ile kadın işgücü yeni bir statü kazanmıştır. Emekçi kadınların uzun mücadeleleri sonucu, dünyanın pek çok ülkesinde çalışma yaşamında eşit ücret, doğum, çocuk bakımı, sosyal güvenlik hakkı gibi firsat eşitliğine ilişkin politikalar kabul edilmiştir (Peker \& Kubar, 2012, s. 174).

Osmanlı'da ise kadınların emek piyasalarında yer alması, Bat'daki gibi Sanayi Devrimi ile başlamamıştı (Koca, 2016). Tanzimat ile başlatılabilecek olan bu süreçle birlikte kadınlar, toplumsal hayata bir özne olarak katılmaya başlamışlardır. Ancak bu dönemdeki katılım, kadınların kendi toplumsal-sınıfsal konumu ile doğrudan ilişkili biçimde bir gelişme göstermiştir (Önder, 2013). Kentli ve ekonomik düzeyi yüksek olan kadınlar gayrimüslim okullarda veya evde aldıkları eğitimle çalışma yaşamına katılırken, düşük gelirli kadınlar kentlerde kurulan atölye tipi sanayide günde 14-15 saat geçimlik ücretle çalışmak zorunda kalmışlardır. Kırsal yörelerdeki kadınlar ise ya Batılı şirketlere halı dokuyarak ilmek başına para almakta, ya da en yoğun olarak aile içi ücretsiz tarım işçiliği yapmaktaydılar (Önder, 2013). Osmanlı döneminde kadınların emek piyasasına katılmaları açısından Balkan Savaşları ile Birinci Dünya Savaşı iki önemli kırılma noktasını teşkil etmektedir (Erdoğan \& Yaşar, 2018; Koca, 2016). Özellikle, gıda ve silah fabrikalarında boşalan işyerleri kadın işgücü ile doldurulmuştur. Çorap imalathaneleri, halı dokuma sektörü gibi tekstil endüstrisinin yanı sıra bankalar, PTT merkezi ve yerel kamu yönetimi ve hastaneler de kapılarını kadınlara açmıştır (Unat, 1988'den aktaran Koca, 2016). Başlangıçta geçici olarak çalışma hayatında yer alan kadınlar, savaşın devam etmesi ile kalıcı olarak emek piyasalarına dâhil olmuşlardır (Koca, 2016). Dolayısıyla Tanzimat ile birlikte çalışma yaşamına ilişkin mevzuat öngörülmüş olsa da, kadın işgücü için düzenleme yapılması ancak Cumhuriyet Dönemi'nde gerçekleşmiştir (Önder, 2013).

1923 yılında Cumhuriyet henüz ilan edilmeden toplanan İzmir İktisat Kongresi'ndeki kararlar, Cumhuriyet Dönemi'nde bu anlamda atlacak adımların habercisi niteliğindeydi. Zira, kadınlara sekiz haftalık doğum izni verilmesi, kadınların madenlerde çalışmalarının yasaklanması gibi iyileştirmeleri de içeren bir takım kararlar alınmıştır (Önder, 2013). Ayrıca 1930 yılında Umumi Hıfzıssıhha Kanunu kapsamında kadın ve çocuk işçiler için izin süreleri, çalışma yaşı kısıt, işin konusu gibi birtakım koruyucu hükümler getirilmiştir (Önder, 2013). 1945 yılında ise İş Kazaları ile Meslek Hastalıkları ve Analık Sigortası Kanunu ile kadın işçilere analık halince sosyal güvenceler sağlanmıştır (Önder, 2013). Türkiye'de kadınların görünürlüklerini artracak türden emek piyasalarına dâhil olmaları ise 1950 'lerden sonra gerçekleşmiştir (Koca, 2016).

Kadının istihdama katılımı günümüzde dahi henüz yeterli düzeyde olmasa da 1950'lerden sonra çeşitli yasal düzenlemeler gerçekleştirilmiştir. Kadınların işgücüne katılımını ve orada tutunmalarını sağlayan dinamiklerin başında ücretler gelmektedir. Kadının işgücüne katılımı kuşkusuz yalnızca ücretlere indirgenemez. Bu anlamda kültürel dinamiklerin de belirleyici bir unsur olduğunu akıldan çıkarmamak gerekir. Ücretlerle ilgili olarak, 1944 yılında ILO tarafindan kabul edilen Philadelphia Bildirisi'nde, ırk ve cinsiyet ayrımı gözetilmeksizin bütün insanların ekonomik güvence ve firsat eşitliğine sahip olduğu vurgulanmıştır (Özdemir vd., 2012). Bu çerçevede, Türkiye'de 1971 yılında yürürlüğe giren 1475 sayılı İş Kanunu ile kadın işgücünü korumaya yönelik kimi hükümlerin yanı sıra eşit işe eşit ücret ilkesi ${ }^{6}$ mevzuata girmiştir (Önder, 2013). 2003 yılında yürürlüğe giren 4587 nolu İş Kanunu'yla da cinsiyet ayrımcılığı yasaklanmış ve eşit işe eşit ücret ilkesi devam etmiştir. Bunun yanı sıra 100 ile 150 kadın işçisi olan işyerleri için bakım ve emzirme odaları kurulması, 150'den fazla işçisi olanlara ise kreş açılmasını düzenleyen hükümler getirilmiştir. Ayrıca 2004 yılında Başbakanlık tarafindan yayınlanan bir genelgede (22.1.2004/2004-7 tarih ve sayılı Genelge), kamuya personel alımında cinsiyet eşitliğinin gözetilmesi istenmiştir (Dedeoğlu, 2009). 2010/14 sayılı genelgede de, kadınların sosyo-ekonomik konumlarının güçlendirilmesi ve istihdamının artırılması ve eşit işe eşit ücret imkânının sağlanmasının şart olduğu (Önder, 2013) daha önceki kararlara ilaveten bir kez daha vurgulanmıştır.

Yasal mevzuatta kadınların istihdam artş̧ına ilişkin çeşitli düzenlemeler olsa da alınan kararların sahaya yansıması aktif teşvik politikalarıyla daha gerçekçi bir zemine oturmaktadır. Kadın istihdamına yönelik teşvikler, 2008-73, 2009-52, 201145 sayılı SGK Genelgeleriyle yayınlanmıştır. Söz konusu teşvik genelgeleriyle kadın ve genç istihdamının artırılması amaçlanmıştır. Bunun da ötesinde Kadınların Dezavantajlı Grupların İstihdamı Halinde Uygulanan Prim Teşvikleri (engelli/genç/ kadın/işsiz/sosyal yardım alanların hepsini kapsamaktadır) 13.01.2011 tarihli 6111 sayılı Kanun'un 74. maddesi ile 4447 sayılı Kanun'a Geçici 10. madde olarak ilave edilmiştir (İzmirlioğlu, 2019). İstihdamın yanı sıra kadın girişimcilerin artırılması konusunda da çeşitli desteklerin olduğu belirtilmelidir. Bu konuda danışmanlık ve destek hizmetlerinde kadınlara öncelik verilmesi, kooperatifleşme ve mikro kredi uygulamalarının geliştirilmesi gibi hususlar aracılığıyla kadın girişimciliğinin artırıması hedeflenmektedir. Destekleyici politikaların On Birinci Kalkınma Planı́nda ön plana çıkarıldığı görülmektedir (Durukan, 2021). ${ }^{7}$ Buraya kadar bahsedilen teşviklerle alakalı

6 Kadın ve erkeğin eşit işte eşit ücret alımına ilişkin düzenleme, 1957'deki Roma Anlaşması'nda da vurgulanmaktadır. Dolayısıyla ayrım gözetmeksizin eşit işe eşit ücret politikası, AB'nin de kurucu ilkelerinden biridir (Gerşil, 2015).

7 Bu konuda detaylı bilgi için On Birinci Kalkınma Planı’nın Kadının Kalkınmadaki Rolü başlıklı Özel İhtisas Komisyonu Raporu’na bakılabilir. 
olarak belirtilmesi gereken husus, kadına yönelik söz konusu teşviklerin bölgesel bir yönünün olmamasıdır. Dolayısıyla bu durum bölgesel yakınsamayı harekete geçirebilecek türden bir uygulama olmamıştır.

\section{Veri ve Yöntem}

Kadın istihdamının toplam istihdam içindeki oranının bölgesel örüntüsünü ortaya koymak ve bölgesel bir yakınsama olup olmadığını analiz etmek için Sosyal Güvenlik Kurumu'nun (SGK) düzey 3 (il) ölçeğindeki zorunlu sigorta sayılarına ilişkin verileri kullanılmıştır ${ }^{8}$. Bilindiği üzere, SGK'nın istihdam verileri TÜiK'teki gibi hanehalkı işgücü anketi şeklindeki örneklem yöntemine değil, kayıtlı bütün istihdam edilenlerin hesaba katıldığı tamsayım yöntemine dayalıdır. SGK'dan elde edilen il ölçeğindeki bu verilere dayalı olarak, kadın istihdamının toplam istihdam içindeki oranı hesaplanmıştır. Burada anti parantez olarak belirtmek gerekir ki kadınlar kayıt dışı olarak daha fazla istihdam edilmektedirler. Bu durum işgücü piyasasında kadınların toplam istihdam içindeki oranının mevcut olandan daha fazla olacağına işaret etmektedir. Bu da yöntemsel açıdan bir sınırlılık olarak ifade edilebilir. Bu yolla, illere göre toplam istihdam içindeki kadın istihdamına ilişkin bir veri seti oluşturulmuştur. Oluşturulan bu veri seti, 2008 ile 2019 yıllarını kapsamaktadır.

Yakınsama çalışmalarında standart sapma değerleri önemli bir gösterge olarak kullanılmaktadır. Dolayısıyla bu çalışmada da yakınsamaya ilişkin yorumlar standart sapma değerlerine dayalı olarak yapılacaktır. Bilindiği üzere standart sapma, gözlemlerin ortalamadan ne kadar uzaklaşthğını göstermektedir (Kalaycı, 2018). Buradan hareketle, standart sapmanın zaman içinde azalma eğilimine girmesi yakınsama, artma eğilimine girmesi ise ıraksama olarak tarif edilmektedir (Sevinç vd., 2016). Bir başka ifadeyle, yıllara göre standart sapma değerlerinde görülen azalmalar bölgelerin birbirine yakınsadığını, yani bölgesel farklılıkların azalma eğilimine girdiğini, standart sapma değerlerinde görülen artı̧lar ise bölgelerin birbirine ıraksadığını yani bölgeler arası farklılaşmanın arttı̆ını ifade etmektedir.

İkinci aşamada ise hangi bölgelerde bir yakınsamanın olduğuna odaklanılmıştır. Bu kapsamda kadınların toplam istihdam içerisindeki oransal artışının yıllık ortalaması (2009-2019) alınarak bu artş̧ oranı Türkiye'deki artış oranlarıyla kıyaslanmıştr. Örneğin, Adana'da 2008 yılında \%20,6 olan kadının toplam istihdamdaki oranı 2009 yılında \%21,1'e çıkmıştır. Dolayısıyla bu örnekteki artş oranı \% 2,43'tür. Bu yolla, referans alınan bütün yılların ve illerin artş oranları hesaplanarak 2009-2019 artş̧ ortalaması elde edilmiştir. Bu yönteme göre Türkiye genelindeki artş ortalamaları da hesap edilmiştir (bkz. Ek1'deki son sütun). Hesap edilen artı̧ ortalamalarının standart sapması üzerinden ise hangi bölgelerin yakınsama hangi bölgele- rin ise ıraksama eğiliminde olduğu tespit edilmiştir. Dolayısıyla standart sapma değeri sıfirdan uzaklaştıkça Türkiye ortalamasından sapmalar da artmaktadır. Şayet bir bölge Türkiye ortalamasının altında bir değere sahip iken artış ortalamasının standart sapması pozitif yönde yüksek bir değer gösteriyorsa o bölgenin yakınsama eğiliminde olduğu söylenebilir. Eğer bir bölge Türkiye ortalamasının altında bir değere sahipken artı̧ oranının standart sapması da negatif yönde yüksek bir değer gösteriyorsa o bölgenin de ıraksama eğiliminde olduğu söylenebilir (bkz. Şekil 2 ve Şekil 3).

\section{Bulgular}

Türkiye'de zorunlu sigortalı sayısı Şekil 1'den de görüleceği üzere sürekli bir artı̧ göstermiştir. 2008-2019 yıllarını kapsayan bu veri setine bakıldığında, erkeklerin sayısı kadınlardan ortalama üç kat daha fazladır. Örneğin, 2008 yılında 2 milyon kadına karşılık, 6.7 milyon erkek zorunlu sigortalı olarak işgücüne katılmıştır. 2019 yılına gelindiğinde ise bu rakamlar kadınlarda 6.7 milyona, erkeklerde ise 16.2 milyona yükselmiştir (Şekil 1). Söz konusu yıllar arasındaki artış, kadınlarda \%330 iken erkeklerde \%240 şeklinde gerçekleşmiştir. Kuşkusuz burada dikkat çekilmesi gereken bir diğer husus da kadınların hangi sektörlerde ve hangi ücret düzeyine sahip işlerde daha çok istihdam edildiğidir. Bu çerçevede 2020 yılında kadınların \%60.3'ü hizmetler, \%22.9'u tarım, \%15.9'u sanayi, \%0.8'i ise inşaat sektöründe çalışmaktadır (TÜiK, 2021).

Türkiye'de kadınların toplam işgücü içindeki hem miktarı hem de oranı genel itibariyle artı̧ eğilimindedir. Nitekim, kadınların toplam istihdam içindeki oranı 2008 yılında \%19.3 iken bu oran, 2012 yılında \%20'lerin, 2017 yılında ise \%25'lerin üzerine çıkmıştır. 2018 yılında kadınların toplam istihdam içindeki oranı \%26,9 ile en yüksek düzeyine çıkmış, 2019 yılında ise bu oran \%26.2 olmuştur (Tablo 1). ${ }^{9}$ Bu değerler, kadınların işgücü içerisinde halen daha düşük oranla temsil edildiklerini göstermekle beraber istihdam içerisinde hem niceliksel hem de oransal olarak ciddi bir artş̧ eğiliminde olduğunu da ortaya koymaktadır. Kadınların erkeklere nazaran kayıt dışı ekonomide daha fazla yer aldığı düşünüldüğünde (Öztürk \& Başar, 2018; ), kadınların işgücü piyasasında bahsedilen değerlerden daha fazla olduğu belirtilebilir. Özetle bu değerler, kadınların işgücü piyasasında erkeklere yakınsamakta olduğunu göstermektedir. Ancak her ne kadar bir yakınsama olsa da, daha önce de vurgulandığı üzere Türkiye'de halen daha OECD ve $A B$ gibi gelişmiş ülkelerin ortalamalarından oldukça düşük değerler söz konusudur. Bahsedilen tarih aralığında kadınların toplam istihdam içerisindeki en düşük oran, \%8.5 ile 2011'de Şırnak'ta, en yüksek oran ise 2018 yılında \%35.5 ile Edirne'de gerçekleşmiştir (Tablo 1, il değerleri için ayrıca bkz. Ek1).

Referans alınan yıllar içerisinde, standart sapma değerlerinde salınımlar görülmektedir. Dolayısıyla süreklilik arz eden

8 Veriler 4a, 4b ve 4c kategorisindeki toplam zorunlu sigortalı sayılarının hepsini kapsamaktadır.

9 Buradaki oranlar kadınların toplam sigortalı içerisindeki oranını ifade etmektedir. Dolayısıyla bu oranlar, kadınların işgücüne katılım oranıyla karıştırılmamalıdır ki bu çalışmadaki değerlendirmeler işgücüne katılım oranları üzerinden değil, toplam istihdam içerisindeki kadınların oranı üzerinden gerçekleştirilmiştir. İşgücüne katılım oranları TÜiK'in hanehalkı işgücü anketlerinde yer almaktadır. Daha önce de ifade edildiği üzere bu çalışmada TÜiK'in örneklem yöntemiyle topladığı veriler değil, SGK'nın tam sayım yöntemine göre olan verileri kullanıldığı için işgücüne katılım oranları kullanılmamıştır. 


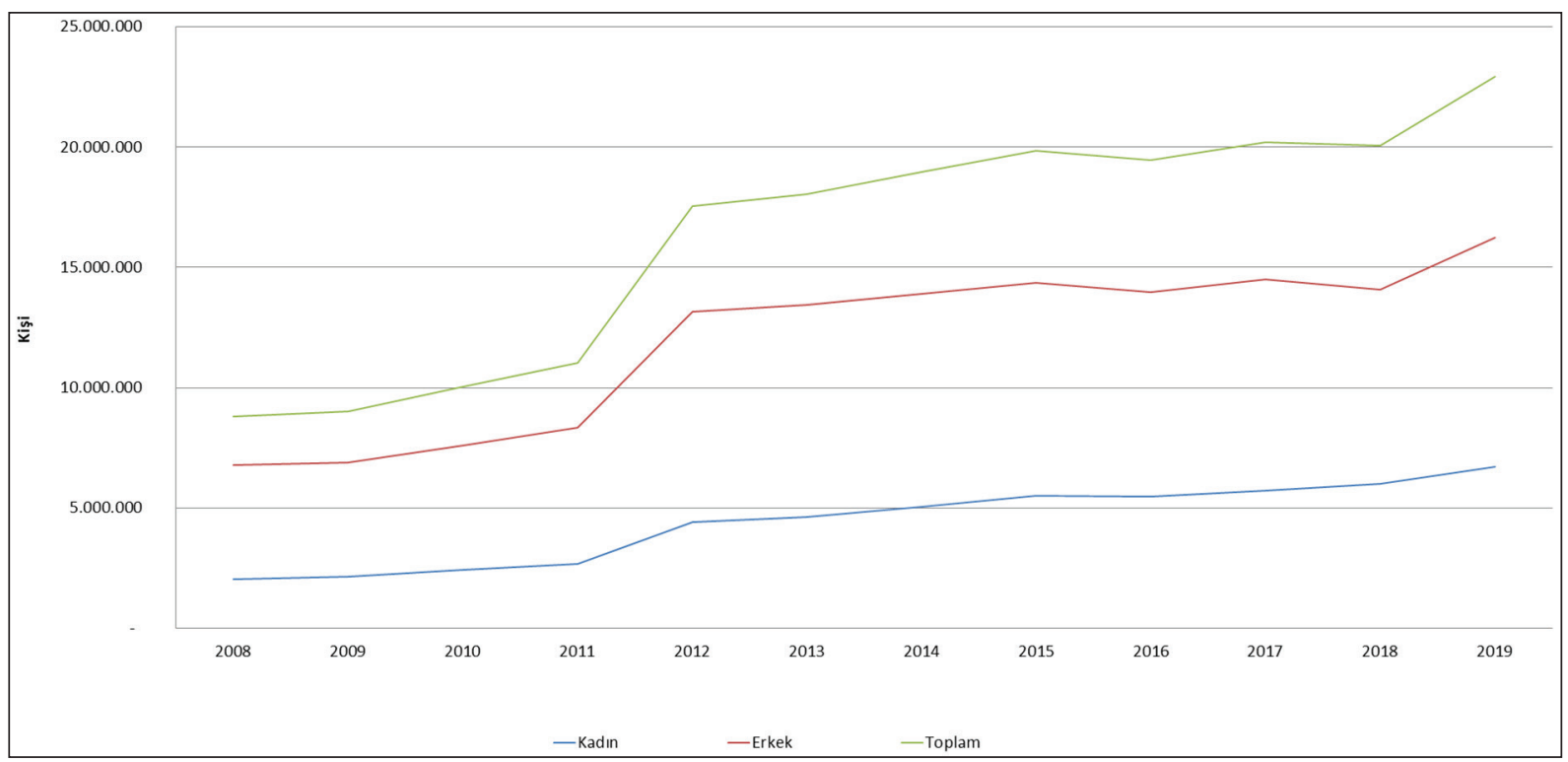

Şekil 1. Zorunlu sigortalı sayısına göre Türkiye'de toplam işgücü miktarı (2008-2019).

Figure 1. The total amount of labour force in Turkey according to the number of compulsory insured persons (2008-2019).

bir düşüş ya da yükselişten bahsetmek mümkün değildir. Zira, 2008 yılındaki standart sapma değeri 4,5 iken bu değer 2011 yılında 5,6'ya yükselmiş, ardından 2016 yılına kadar sürekli bir düşüş göstererek 4,4'e kadar inmiştir. 2016 yılından sonra ise yeniden yükselişe geçerek 2019 yılında 4,9 değerine ulaşmıştır. Daha önce de ifade edildiği üzere, standart sapma değerlerinin düşük olduğu tarihler yakınsamanın gerçekleştiği yılları, yüksek olduğu tarihler ise ıraksamanın gerçekleştiği yılları ifade etmektedir. Salınım gösteren bu değerler, yakınsamanın da ıraksamanın da süreklilik arz etmediğini göstermektedir. Bu durum, kadının istihdamını artırmaya yönelik bölgesel ölçekte bir politikanın uygulanmadığına işaret etmektedir. Standart sapma değerinin en düşük olduğu 2016 yılı, bölgesel ölçekte Türkiye'de yakınsamanın en fazla gerçekleştiği yıl olarak değerlendirilebilir. 2008-2019 yıllarını kapsayan on iki yıllık dönem üç yıllık periyotlara ayrıldığında, standart sapma ortalamasının en az olduğu periyodun 2014-2016 yılları kapsayan dönemde gerçekleştiği görülmektedir. Bir başka ifadeyle 2014-2016 yıllarını kapsayan üç yıllık periyot, Türkiye'de bölgesel yakınsamanın en fazla gerçekleştiği dönem olarak ön plana çıkmaktadır (Tablo 1).

Ek1'de de detayları görüleceği üzere 2008-2019 yıllarını kapsayan dönemde Denizli, on iki yıl üst üste toplam istihdam içerisinde kadın istihdam oranının istikrarlı biçimde en fazla olduğu ilk üç il arasında yer almıştır. Denizli'nin kadın istihdamında lider bir pozisyonda yer alması, ildeki sektörel yapıyla ilişkili bir durumdur. Nitekim, KEiG (2013) tarafindan yapılan bir araşttrmada da belirtildiği üzere Denizli'nin Türkiye'de tekstil sektöründe öncü bir il olması -ki tekstil sektörü kadın istihdamının en çok olduğu faaliyetler arasında ilk sıralarda yer alır - Denizli'yi kadın istihdamında da öncü bir il haline getirmiştir. İstikrarlı seyir izleyen bir diğer il, on bir kez üst üste ilk üç il arasında yer alan İzmir'dir. İzmir, yalnızca 2016 yılında fire vererek ilk üç il arasında yer alamamıştır. Benzer şekilde İzmir'deki sektörel yapının da kadın istihdamının yüksek olmasıyla ilişkili olduğu belirtilmektedir (KEIG, 2013). Nitekim ilin tekstil sanayinin yanı sıra perakende ticaret, turizm ve tarım sektörlerinde de ön planda olması İzmir'i kadın istihdamı konusunda önemli bir pozisyona taşımaktadır (KEIG, 2013). İstikrarıı bir şekilde ilk üç il arasında yer alan bir diğer il ise Edirne olmuştur. Edirne de on iki yılda dokuz kez ilk üç il arasında yer alarak toplam istihdam içerisinde kadın istihdam oranının en fazla olduğu il olmuştur. Denizli, İzmir ve Edirne haricinde İstanbul üç kez, Ankara ise bir kez ilk üç il arasına girmişlerdir. Ancak bu illerde istikrarlı bir eğilim söz konusu değildir (bkz. Ek1). Bahsedilen on iki yıllık periyotta, toplam istihdam içerisinde kadın istihdam oranının istikrarlı biçimde en az olduğu ilk üç il ise Siirt, Şırnak ve Hakkari'dir. Siirt on bir kez, Şırnak on kez, Hakkari ise yedi kez en az orana sahip ilk üç il arasında yer almıştır (bkz. Ek1). Yukarıda verilen bilgilerden hareketle aynı illerin adeta kronikleşen türden bir eğilim içerisinde olduğu görülmektedir. Illerdeki sektörel yapının kadın istihdamını etkilediğine dair yukarıda verilen bilgilerden hareketle Siirt, Şırnak ve Hakkari'nin

Tablo 1. Betimsel istatistik sonuçları.

Table 1. Descriptive statistic results.

\begin{tabular}{lcccccccccccc}
\hline & $\mathbf{2 0 0 8}$ & $\mathbf{2 0 0 9}$ & $\mathbf{2 0 1 0}$ & $\mathbf{2 0 1 1}$ & $\mathbf{2 0 1 2}$ & $\mathbf{2 0 1 3}$ & $\mathbf{2 0 1 4}$ & $\mathbf{2 0 1 5}$ & $\mathbf{2 0 1 6}$ & $\mathbf{2 0 1 7}$ & $\mathbf{2 0 1 8}$ & $\mathbf{2 0 1 9}$ \\
\hline N Valid & 81 & 81 & 81 & 81 & 81 & 81 & 81 & 81 & 81 & 81 & 81 & 81 \\
Ortalama & 19,3 & 19,9 & 19,9 & 19,2 & 21,1 & 21,7 & 22,8 & 24,5 & 24,9 & 25,4 & 26,9 & 26,2 \\
Ort. Standart hata &, 50 &, 51 &, 52 &, 62 &, 54 &, 54 &, 53 &, 50 &, 49 &, 51 &, 53 &, 54 \\
Standart sapma & 4,5 & 4,6 & 4,7 & 5,6 & 4,9 & 4,9 & 4,8 & 4,5 & 4,4 & 4,6 & 4,8 & 4,9 \\
Minimum & 12,3 & 12,8 & 12,9 & 8,5 & 11,4 & 11,9 & 12,6 & 14,8 & 14,7 & 13,8 & 14,3 & 13,6 \\
Maksimum & 30,4 & 30,6 & 30,3 & 30,1 & 30,3 & 30,5 & 31,8 & 32,4 & 32,9 & 33,9 & 35,5 & 34,5 \\
\hline
\end{tabular}


sektörel yapısının kadınların daha fazla istihdam edildiği alanlarda olmayışı etkilidir. Bunun yanı sıra Cihangir vd.'nin (2020) de ortaya koyduğu üzere söz konusu bölgelerde kadının üretim sürecinde çok aktif olduğu ancak bunun daha çok ev işlerinin bir devamı olarak görüldüğü dolayısıyla ücretsiz ve sigortasız bir biçimde gerçekleştiğini de hatırdan çıkarmamak gerekir. Bu gerçekten hareketle, bu bölgelerde kadın, üretim sürecinde aktif bir biçimde rol alsa da bu durum ücretli ve kayıtlı istihdama dönüşmemektedir (Cihangir vd., 2020). Dolayısıyla bu illerdeki kadın istihdamına ilişkin düşüklüğün nedeni söz konusu illerde kadının kayıtlı olarak istihdam edilebileceği sanayi faaliyetlerinin yoksunluğunun yanı sıra tarım gibi ücretsiz aile işçiliğinin yoğun olmasıyla da alakalıdır. Türkiye'de doğu-bat kültürel dikotomisi düşünüldüğünde söz konusu oranların yüksek ya da düşük olmasının ardında bir takım kültürel dinamiklerin olabileceğini de hatırdan çıkarmamak gerekir. Ancak doğu-bat karşılaştırması yapacak şekilde bir tasarım yapmak bu araştırmanın sınırlarını aşan ancak başka araştırmalara konu oluşturabilecek türdendir.

Kadınların toplam istihdam içerisindeki oranının yıllara göre nasıl bir mekânsal örüntüye sahip olduğu, Şekil 2'deki haritadan detaylı biçimde izlenebilir. Genel itibariyle sahil şeridi ile iç bat bölgeleri, kadın istihdamının toplam istihdam içerisindeki oranı açısından Türkiye ortalamasının üzerindedir (Şekil 2).

Yukarıdaki bilgiler kadın istihdamına ilişkin genel bir yapıyı ortaya koymaktadır. Çalışmanın asıl odağını oluşturan yakınsama olgusunun nerelerde gerçekleştiğini anlamak için kadın istihdam oranının standart sapması üzerinden değerlendirmeler yapılmıştır. Buna göre 2008-2019 tarihleri arasında kadının toplam istihdam içerisindeki oransal artş̧ına ilişkin standart sapma değerinin pozitif yönde en yüksek değer aldığı Zonguldak, Kırıkkale, Rize, Kütahya, ve Artvin'den oluşan beş il en fazla yakınsayan iller olarak tespit edilmiştir (Şekil 3, koyu yeşil renkli iller). Ek 1'den de takip edilebileceği üzere söz konusu iller Türkiye ortalamasının oldukça üzerinde bir artş oranına sahip olan illerdir. İkincil derecede yakınsamanın en fazla gerçekleştiği iller ise Şekil 3'teki açık mavi renk alan illerdir. Dolayısıyla, yakınsamanın genel itibariyle Türkiye'nin kuzeydeki sahil şeridinde ve iç bölgelerinde gerçekleştiği görülmektedir. Özetle Şekil 3'teki koyu mavi ve açık mavi renk alan iller yakınsamanın gerçekleştiği bölgeleri göstermektedir. Yani, Şekil 2'deki haritada Türkiye ortalamasının altında değer alan bölgeler, yakınsama eğilimindedir. Şekil 3'teki sarı renk alan illerin ise Türkiye ortalamasına yakın değerlerde bir artş̧ oranına sahip olduğu belirtilebilir. Bu illerdeki durumun stabil bir seyirde olduğu belirtilebilir.

Iraksamanın görüldüğü bölgelerin sayısı ise görece daha azdır. Zaten Türkiye ortalamasının oldukça altında değerler gösteren Ardahan ve Hakkari en fazla ıraksayan il grubunu oluşturmaktadır (Şekil 3, koyu kahverengi olan iller). Íkincil derecede ıraksamanın gerçekleştiği il grubunu bir ton açık kahverengi alan Şırnak ve Tunceli oluşturmaktadır (Şekil 3).

En açık kahve tonunu alan Türkiye'nin batısındaki İstanbul, İzmir, Edirne, Bursa, Aydın ve Denizli gibi iller ise zaten Türkiye ortalamasının üzerinde bir değer gösterdiğinden bu bölgelerde bir ıraksama değil bir duraksamadan bahsedilebilir.



Şekil 2. Kadın istihdam oranının Türkiye ortalamasının altında ve üstünde olduğu iller (2008-2019). Kaynak: SGK verilerinden yararlanılarak oluşturulmuştur. Figure 2. Provinces where the female employment rate is below and above the Turkish average (2008-2019). 




Şekil 3. Kadın istihdamının artış oranındaki ortalamanın standart sapması.

Figure 3. Standard deviation in the rate of increase average in women employment.

\section{Sonuç}

En gelişmiş olanından en geri kalmışına kadar ülkelerin gündemini belirleyen en önemli dinamik, ekonomidir. Bu çerçevede, üretim faktörlerinin etkin ve verimli bir biçimde kullanılması, kalkınmanın gerçekleşmesi ve kalıcı istikrarın sağlanması için önemli bir husus olarak dikkat çekmektedir. Bununla ilişkili olarak, üretim faktörleri arasında gösterilen emeğin etkin ve verimli olarak kullanılması, kalkınmayı sağlayan önemli güçlerden biri olarak belirmektedir. Nitekim, toplumların sosyal, siyasal ve ekonomik alanda cinsiyet ayrımı gözetmeden eşitlikçi bir yapıda olup olmamaları, aynı zamanda kalkınma göstergesi olarak da kullanılmaktadır. Buna yönelik olarak kadının işgücü piyasasında yer alması, ekonomik olduğu kadar sosyal ve siyasal açıdan da kadının toplumdaki statüsüne pozitif yönde yansımaktadır (Bacchus, 2005). Bu sayede emeğin etkin bir pozisyona sokularak kalkınmaya katkısı da gerçekleşmektedir. Bu bağlamda, küresel ölçekte kadının işgücü piyasasındaki görünürlüğünde ciddi artşlar gözlenmektedir. Öyle ki, kadın istihdamının toplam istihdam içerisinde erkeklerle eşitlenme eğiliminde olması, gelişmiş ülkelerin işgücü piyasalarının bir karakteristiği haline gelmiştir. Gelişmiş ülkelerin böylesi bir karakteristiğe sahip olması, gelişmekte olan ülkeler için de emsal niteliği taşımaktadır (Alkan \& Alkan, 2018).

Bu araştırmayla ortaya konulduğu üzere Türkiye'de kadınların toplam istihdam içerisindeki oranı 2008-2019 yıllarını kapsayan dönemde istikrarlı bir biçimde artmıştır. Söz konusu istikrarlı artışın, bölgesel yakınsamaya da pozitif etki ettiği görülmektedir. Bu durum, kadının toplam istihdam içerisindeki oranının düşük olduğu bölgelerin yüksek olan bölgelerle aradaki farkı kapatma eğiliminde olduğunu göstermektedir. Yakınsama eğilimine ilişkin bu bulgu, farklı veriler kullanılarak Karahasan ve Bilgel (2018) tarafindan gerçekleştirilen araştırmanın bulgularıyla örtüşmektedir. Nitekim kadının istihdam içerisindeki görünürlüğünün artışı, kadının toplumsal rolünü güçlendirerek sosyal ve kültürel hareketlenmeyi sağlaması açısından da önemlidir. Öyle ki kadının işgücüne katılımı, istihdamdan çok öte bir anlama sahiptir. Gerçekten de kadının ekonomik açıdan aktif olması şiddet, gelir dağılımı adaletsizliği, karar alma mekanizmalarında rol alma, eğitim ve sağlık imkânlarından istifade etme gibi pek çok hususa da yansımaktadır. Hatta daha da ileri giderek Marx’ın ifade ettiği şekliyle ifade edilecek olunursa, toplumdaki maddi egemen güç, aynı zamanda egemen bir entelektüel güç haline gelmektedir. Bir başka ifadeyle, sermaye gibi bir üretim aracını elini tutan güç, toplumda düşünsel üretim araçlarını da kontrol etmeye muktedir olacaktır (Donovan, 2015). Bu düşünceden hareketle kadının ekonomik açıdan güçlü olması toplumda düşünsel üretim araçlarındaki etkisine de yansıyacaktır. Dolayısıyla yakınsamanın kadın istihdamı açısından gerçekleşmesinin yalnızca ekonomik değil sosyal ve kültürel alanlara da etki yapacağı muhakkaktır. Kuşkusuz bu eğilimin istikrarlı bir sürece dönüşmesi önemlidir. Nitekim Şekil 2'den de takip edilebileceği üzere kadının toplam istihdam içerisindeki oranı açısından halen daha belirgin bir bölgesel farklılık söz konusudur. Bu anlamda, cinsiyet temelli bölgesel teşvik politikalarının gündeme getirilmesi, yakınsama eğiliminin istikrarlı ve kalıcı bir sürece döndürülmesi için önemli bir girişim olabilecektir. Burada dikkate alınması gereken bir diğer husus da kadının yalnızca istihdamının artırılması değil aynı zamanda ücret düzeyinin de yükseltilmesidir. Yalnızca istihdamın artırılarak ücret düzeylerinin düşük olması, kadın istihdamını bir emek sömürüsüne dönüştüreceği gibi Walby’nin (2021) ifadesiyle patriyarkanın özel alandan kamusal alana kayması anlamına da gelecektir. Bu durum kadının ücretli emeğe dahil olmasını özgürleşme yaratan bir dinamik olmaktan ziyade kamusal alana taşınan yeni bir tahakküm biçimi olarak değerlendirmeye imkan tanımaktadır (Walby, 2021). Dolayısıyla bölgesel ölçekte kadın istihdamındaki artışın yanı sıra yine bölgesel ölçekte ücret düzeylerindeki artışın çalışılması da gelecekteki araştırmalara konu teşkil edebilecek türdendir. 
EK1. Illere göre toplam istihdam içinde kadın istihdamının oranı ve 2009-2019 artı̧ ortalaması.

Addition 1. The rate of female employment in total employment by provinces and the average increase in 2009-2019.

\begin{tabular}{|c|c|c|c|c|c|c|c|c|c|c|c|c|c|}
\hline $\begin{array}{l}\text { il plaka } \\
\text { kodu }\end{array}$ & 2008 & 2009 & 2010 & 2011 & 2012 & 2013 & 2014 & 2015 & 2016 & 2017 & 2018 & 2019 & $\begin{array}{l}\text { Artş oranı ortala- } \\
\text { ması }(2009-2019)^{10}\end{array}$ \\
\hline 01 & 20,6 & 21,1 & 21,0 & 20,9 & 23,6 & 24,1 & 25,1 & 26,2 & 26,2 & 27,2 & 29,0 & 28,6 & 3,1 \\
\hline 02 & 22,3 & 19,6 & 18,8 & 16,6 & 18,0 & 18,7 & 19,0 & 19,8 & 21,4 & 22,1 & 23,6 & 23,5 & 0,7 \\
\hline 03 & 16,1 & 17,6 & 17,3 & 16,7 & 18,6 & 18,9 & 19,9 & 21,3 & 22,7 & 23,1 & 25,2 & 24,5 & 4,0 \\
\hline 04 & 21,2 & 20,6 & 17,8 & 11,2 & 14,8 & 15,8 & 17,4 & 18,8 & 21,2 & 20,4 & 20,8 & 19,7 & 0,8 \\
\hline 05 & 17,7 & 18,6 & 18,1 & 18,0 & 21,1 & 22,7 & 23,8 & 26,2 & 25,7 & 26,7 & 28,6 & 28,1 & 4,4 \\
\hline 06 & 23,5 & 26,4 & 26,3 & 26,6 & 29,0 & 29,0 & 29,9 & 31,8 & 32,5 & 30,9 & 32,3 & 32,2 & 3,0 \\
\hline 07 & 23,7 & 25,2 & 25,5 & 25,9 & 25,5 & 26,1 & 27,4 & 28,5 & 29,9 & 30,8 & 32,4 & 31,5 & 2,7 \\
\hline 08 & 13,9 & 14,3 & 14,8 & 14,0 & 19,2 & 20,5 & 21,3 & 24,2 & 23,3 & 25,2 & 25,9 & 24,9 & 6,0 \\
\hline 09 & 24,9 & 26,4 & 26,2 & 26,5 & 26,2 & 26,9 & 27,7 & 28,7 & 28,6 & 29,3 & 32,0 & 30,3 & 1,9 \\
\hline 10 & 20,3 & 21,0 & 22,3 & 22,8 & 24,3 & 24,5 & 25,9 & 27,5 & 27,8 & 28,7 & 30,3 & 30,5 & 3,8 \\
\hline 11 & 16,7 & 15,8 & 17,4 & 19,5 & 22,3 & 23,2 & 25,3 & 27,2 & 27,3 & 27,7 & 28,4 & 28,1 & 5,0 \\
\hline 12 & 15,0 & 16,7 & 16,1 & 14,6 & 14,9 & 15,4 & 17,5 & 20,5 & 18,8 & 18,9 & 19,7 & 19,3 & 2,6 \\
\hline 13 & 16,6 & 16,6 & 15,4 & 10,1 & 13,0 & 13,4 & 14,9 & 17,6 & 18,3 & 18,3 & 19,8 & 18,7 & 2,4 \\
\hline 14 & 23,2 & 24,7 & 24,7 & 25,2 & 26,5 & 26,7 & 28,4 & 30,9 & 31,0 & 32,1 & 33,4 & 32,8 & 3,2 \\
\hline 15 & 17,3 & 18,3 & 19,5 & 19,4 & 23,9 & 24,2 & 25,7 & 28,3 & 27,0 & 28,2 & 30,4 & 30,0 & 5,4 \\
\hline 16 & 25,6 & 26,2 & 26,5 & 26,7 & 27,9 & 28,6 & 29,4 & 30,1 & 30,6 & 31,0 & 32,3 & 31,8 & 2,0 \\
\hline 17 & 21,5 & 22,7 & 22,9 & 22,9 & 25,3 & 25,9 & 27,0 & 29,1 & 28,7 & 29,5 & 31,1 & 30,5 & 3,3 \\
\hline 18 & 17,1 & 17,9 & 17,3 & 18,4 & 20,5 & 21,2 & 22,0 & 24,2 & 23,8 & 24,8 & 26,5 & 25,8 & 3,9 \\
\hline 19 & 20,6 & 20,3 & 20,7 & 20,9 & 21,5 & 22,3 & 23,3 & 25,4 & 25,9 & 26,7 & 28,7 & 28,3 & 3,0 \\
\hline 20 & 30,4 & 30,5 & 30,3 & 30,1 & 30,3 & 30,5 & 31,8 & 32,4 & 32,9 & 33,3 & 35,3 & 34,5 & 1,2 \\
\hline 21 & 16,0 & 17,0 & 16,7 & 14,9 & 17,5 & 18,5 & 19,1 & 20,3 & 20,9 & 20,8 & 22,5 & 22,3 & 3,3 \\
\hline 22 & 27,8 & 28,9 & 29,5 & 29,2 & 27,8 & 28,9 & 30,7 & 32,2 & 32,5 & 33,9 & 35,5 & 32,9 & 1,6 \\
\hline 23 & 14,3 & 14,6 & 14,2 & 14,9 & 17,4 & 17,9 & 18,8 & 20,3 & 20,9 & 20,9 & 24,1 & 23,6 & 4,8 \\
\hline 24 & 15,0 & 15,7 & 16,9 & 17,4 & 18,1 & 18,5 & 19,5 & 21,7 & 22,4 & 22,0 & 23,8 & 23,5 & 4,2 \\
\hline 25 & 15,0 & 16,3 & 15,8 & 14,3 & 16,8 & 17,0 & 18,3 & 19,6 & 20,8 & 21,6 & 23,2 & 22,0 & 3,8 \\
\hline 26 & 22,6 & 22,8 & 24,2 & 24,7 & 27,4 & 27,9 & 29,2 & 30,8 & 31,1 & 31,0 & 32,9 & 32,5 & 3,4 \\
\hline 27 & 14,0 & 14,9 & 14,7 & 13,8 & 15,7 & 16,1 & 17,1 & 18,4 & 19,3 & 19,5 & 21,1 & 20,7 & 3,8 \\
\hline 28 & 24,9 & 25,2 & 25,6 & 25,7 & 26,4 & 26,6 & 28,7 & 30,0 & 30,9 & 31,5 & 32,9 & 32,2 & 2,4 \\
\hline 29 & 16,2 & 17,6 & 17,0 & 14,8 & 18,4 & 18,7 & 21,3 & 24,8 & 23,5 & 25,5 & 25,5 & 25,0 & 4,5 \\
\hline 30 & 20,8 & 19,1 & 16,8 & 13,4 & 12,3 & 12,2 & 13,8 & 17,4 & 14,9 & 14,7 & 15,7 & 13,6 & $-3,0$ \\
\hline 31 & 15,9 & 16,4 & 16,8 & 16,9 & 19,5 & 19,6 & 20,9 & 22,8 & 23,6 & 24,6 & 25,9 & 25,8 & 4,6 \\
\hline 32 & 20,7 & 22,6 & 23,8 & 23,9 & 25,0 & 25,5 & 26,5 & 28,1 & 28,6 & 28,4 & 28,3 & 28,1 & 2,9 \\
\hline 33 & 21,1 & 21,6 & 21,9 & 21,5 & 22,6 & 22,5 & 23,9 & 25,1 & 25,6 & 26,2 & 28,0 & 27,0 & 2,3 \\
\hline 34 & 27,0 & 27,9 & 28,5 & 28,9 & 29,5 & 29,9 & 30,8 & 31,2 & 31,6 & 31,6 & 33,3 & 32,4 & 1,7 \\
\hline 35 & 27,6 & 28,3 & 28,8 & 29,2 & 30,3 & 30,4 & 31,4 & 31,9 & 31,8 & 32,1 & 33,7 & 33,1 & 1,7 \\
\hline 36 & 21,2 & 22,0 & 20,6 & 17,2 & 18,8 & 18,8 & 20,2 & 21,8 & 21,4 & 23,5 & 24,3 & 22,2 & 0,8 \\
\hline 37 & 18,8 & 19,7 & 20,9 & 20,9 & 21,0 & 22,0 & 23,1 & 24,1 & 25,1 & 25,5 & 26,4 & 25,8 & 2,9 \\
\hline 38 & 15,1 & 15,5 & 15,7 & 16,3 & 19,3 & 19,6 & 20,8 & 22,2 & 23,1 & 23,6 & 25,1 & 24,8 & 4,7 \\
\hline 39 & 26,9 & 28,1 & 28,0 & 28,0 & 27,5 & 28,2 & 29,3 & 30,3 & 30,4 & 31,6 & 33,2 & 31,9 & 1,6 \\
\hline 40 & 15,5 & 15,4 & 16,2 & 15,9 & 20,5 & 20,6 & 21,7 & 23,8 & 23,7 & 23,3 & 25,3 & 25,8 & 5,1 \\
\hline 41 & 18,4 & 19,5 & 20,5 & 20,8 & 22,9 & 23,4 & 24,4 & 26,1 & 26,6 & 27,0 & 28,3 & 28,6 & 4,1 \\
\hline 42 & 12,8 & 13,8 & 14,4 & 14,8 & 17,4 & 17,9 & 18,7 & 20,1 & 21,0 & 21,3 & 22,7 & 22,0 & 5,2 \\
\hline 43 & 14,0 & 15,1 & 16,5 & 16,5 & 19,3 & 20,4 & 21,6 & 23,3 & 24,4 & 24,9 & 26,8 & 27,0 & 6,2 \\
\hline 44 & 18,1 & 18,9 & 19,0 & 17,9 & 19,7 & 20,7 & 21,1 & 22,8 & 23,8 & 23,8 & 24,9 & 24,8 & 3,0 \\
\hline 45 & 21,6 & 21,5 & 22,4 & 23,0 & 23,2 & 23,5 & 25,1 & 25,8 & 26,5 & 27,0 & 28,7 & 28,5 & 2,6 \\
\hline
\end{tabular}




\begin{tabular}{|c|c|c|c|c|c|c|c|c|c|c|c|c|c|}
\hline 46 & 13,1 & 13,2 & 13,8 & 13,4 & 15,9 & 17,1 & 17,6 & 18,5 & 19,5 & 19,9 & 21,5 & 21,1 & 4,6 \\
\hline 47 & 15,4 & 15,8 & 13,9 & 10,4 & 13,3 & 14,5 & 14,7 & 15,6 & 17,6 & 17,1 & 19,0 & 19,1 & 2,9 \\
\hline 48 & 20,2 & 21,5 & 22,4 & 22,5 & 24,7 & 25,2 & 26,3 & 27,7 & 27,9 & 28,3 & 30,0 & 29,5 & 3,6 \\
\hline 49 & 18,9 & 19,6 & 18,9 & 12,8 & 15,7 & 15,7 & 17,8 & 19,1 & 21,4 & 21,1 & 21,3 & 20,9 & 1,9 \\
\hline 50 & 18,2 & 18,8 & 20,3 & 20,3 & 20,0 & 20,1 & 21,3 & 22,6 & 24,2 & 24,3 & 26,3 & 24,7 & 2,9 \\
\hline 51 & 17,5 & 17,1 & 18,4 & 17,3 & 18,0 & 18,7 & 19,6 & 21,4 & 21,1 & 21,9 & 23,5 & 22,6 & 2,5 \\
\hline 52 & 26,5 & 26,2 & 27,3 & 26,5 & 25,8 & 27,2 & 28,0 & 29,1 & 30,0 & 31,0 & 33,2 & 32,5 & 1,9 \\
\hline 53 & 16,1 & 17,4 & 18,3 & 18,7 & 25,3 & 25,8 & 26,7 & 28,9 & 28,1 & 29,8 & 30,8 & 31,4 & 6,6 \\
\hline 54 & 19,4 & 20,8 & 21,5 & 21,7 & 23,3 & 24,4 & 25,5 & 26,4 & 27,5 & 28,1 & 29,8 & 29,2 & 3,8 \\
\hline 55 & 22,0 & 23,4 & 23,4 & 22,9 & 25,4 & 26,5 & 27,8 & 29,2 & 29,8 & 30,1 & 32,2 & 32,1 & 3,6 \\
\hline 56 & 14,1 & 13,7 & 13,1 & 9,7 & 12,0 & 12,5 & 13,8 & 14,8 & 16,3 & 15,7 & 17,8 & 15,7 & 1,9 \\
\hline 57 & 24,9 & 23,0 & 23,7 & 23,9 & 25,0 & 26,5 & 27,5 & 29,0 & 28,6 & 30,2 & 32,2 & 31,1 & 2,1 \\
\hline 58 & 14,1 & 15,0 & 15,3 & 14,6 & 17,5 & 17,9 & 19,1 & 20,9 & 21,5 & 22,3 & 23,8 & 23,1 & 4,8 \\
\hline 59 & 27,0 & 26,8 & 27,1 & 27,7 & 28,1 & 28,6 & 29,5 & 30,0 & 30,4 & 30,5 & 31,7 & 31,1 & 1,3 \\
\hline 60 & 18,5 & 19,1 & 19,0 & 19,0 & 19,3 & 20,2 & 22,0 & 23,4 & 24,6 & 25,3 & 27,5 & 26,3 & 3,3 \\
\hline 61 & 21,5 & 21,9 & 22,3 & 22,4 & 24,9 & 25,3 & 26,1 & 27,8 & 28,8 & 30,2 & 31,4 & 30,5 & 3,3 \\
\hline 62 & 21,1 & 21,4 & 21,0 & 20,8 & 20,9 & 21,0 & 20,8 & 24,5 & 20,2 & 21,3 & 23,0 & 19,9 & $-0,1$ \\
\hline 63 & 13,0 & 15,4 & 14,5 & 11,1 & 14,2 & 14,8 & 15,8 & 17,2 & 18,7 & 19,4 & 21,3 & 20,3 & 5,0 \\
\hline 64 & 22,9 & 25,0 & 25,3 & 24,7 & 27,0 & 27,1 & 28,4 & 29,3 & 29,1 & 30,6 & 32,5 & 32,3 & 3,2 \\
\hline 65 & 14,8 & 15,7 & 14,8 & 10,1 & 13,8 & 15,5 & 16,6 & 17,9 & 21,3 & 19,9 & 21,2 & 21,1 & 4,6 \\
\hline 66 & 15,5 & 15,4 & 14,8 & 13,2 & 16,4 & 17,0 & 17,7 & 19,8 & 21,4 & 22,7 & 23,5 & 23,1 & 4,0 \\
\hline 67 & 13,8 & 15,1 & 16,5 & 16,5 & 21,8 & 22,7 & 23,6 & 25,0 & 25,8 & 26,7 & 28,5 & 28,2 & 7,0 \\
\hline 68 & 15,0 & 15,5 & 15,6 & 15,5 & 17,9 & 18,5 & 19,6 & 20,6 & 21,8 & 22,4 & 24,2 & 23,6 & 4,3 \\
\hline 69 & 12,9 & 14,0 & 13,3 & 14,2 & 15,1 & 15,7 & 17,3 & 21,2 & 20,6 & 22,6 & 22,5 & 20,9 & 4,8 \\
\hline 70 & 23,7 & 26,4 & 26,1 & 27,3 & 26,3 & 26,9 & 27,4 & 28,3 & 28,7 & 28,3 & 29,9 & 28,5 & 1,8 \\
\hline 71 & 12,3 & 12,8 & 13,5 & 13,2 & 17,7 & 18,3 & 19,4 & 21,5 & 22,1 & 23,1 & 24,8 & 25,0 & 7,0 \\
\hline 72 & 13,8 & 14,2 & 13,7 & 10,8 & 15,0 & 16,0 & 18,4 & 20,0 & 20,7 & 21,2 & 22,7 & 22,6 & 5,5 \\
\hline 73 & 16,7 & 14,4 & 12,9 & 8,5 & 11,4 & 11,9 & 12,6 & 15,3 & 14,7 & 13,8 & 14,3 & 14,4 & 0,2 \\
\hline 74 & 24,8 & 23,8 & 24,1 & 23,8 & 26,3 & 26,3 & 27,2 & 28,4 & 28,6 & 28,8 & 32,1 & 32,3 & 2,5 \\
\hline 75 & 26,3 & 26,6 & 22,5 & 18,9 & 17,4 & 16,5 & 18,9 & 22,0 & 20,4 & 19,1 & 20,3 & 19,5 & $-2,2$ \\
\hline 76 & 19,9 & 20,8 & 18,6 & 15,8 & 19,4 & 20,5 & 21,3 & 24,2 & 25,2 & 25,0 & 26,4 & 24,1 & 2,3 \\
\hline 77 & 22,7 & 22,9 & 23,1 & 23,2 & 25,9 & 25,8 & 25,1 & 25,7 & 26,0 & 26,2 & 26,8 & 25,7 & 1,2 \\
\hline 78 & 16,4 & 16,9 & 16,7 & 19,0 & 22,2 & 23,1 & 24,5 & 27,6 & 27,6 & 27,0 & 27,3 & 27,6 & 5,0 \\
\hline 79 & 20,3 & 18,2 & 18,9 & 15,1 & 17,4 & 18,2 & 18,8 & 22,7 & 23,8 & 26,0 & 25,8 & 22,9 & 1,8 \\
\hline 80 & 17,2 & 17,4 & 17,6 & 18,0 & 20,3 & 20,6 & 22,0 & 23,5 & 23,6 & 24,7 & 26,4 & 26,1 & 3,9 \\
\hline 81 & 26,4 & 27,7 & 28,4 & 28,5 & 28,9 & 29,1 & 29,8 & 30,3 & 31,8 & 32,0 & 33,6 & 32,8 & 2,0 \\
\hline TR ort & 19,3 & 19,9 & 19,9 & 19,2 & 21,1 & 21,7 & 22,8 & 24,5 & 24,9 & 25,4 & 26,9 & 26,2 & 2,9 \\
\hline
\end{tabular}

\section{Kaynakça}

Abdioğlu, Z., \& Uysal, T. (2013). Türkiye'de bölgeler arası yakınsama: Panel birim kök analizi. Atatürk Üniversitesi iktisadi ve Idari Bilimler Dergisi, 27(3), 125-143. https://dergipark.org.tr/en/pub/ atauniiibd/issue/2710/35741

Akpınar, R. (2017). Yerel kalkınmada bölge ölçeğinde kurumsal yapılanma: Bölge kalkınma idaresi başkanlıkları. Aksaray Üniversitesi iktisadi ve Idari Bilimler Fakültesi Dergisi, 9(1), 13-22. https:// dergipark.org.tr/en/pub/aksarayiibd/issue/34899/386998

Alkan, I., \& Alkan, B. (2018). Türkiye'de kadın istihdam örüntülerinde bölgesel farklııklar. İçinde Y. Bayar (Ed.), 4th SCF International Conference on Economics and Social Impacts of Globalization and Future Turkey-EU Relations (ss. 33-48).
Aşık, O. G. (2013). Türkiye'yi kadınlar büyütebilir mi? TEPAV Politika Notu. https://www.tepav.org.tr/upload/files/1361452044-2. Turkiye yi Kadinlar Buyutebilir mi.pdf

Ataay, F. (2001). Türkiye kapitalizminin mekansal dönüşümü. Praksis, 2, 53-96. http://www.praksis.org/wp-content/uploads/2011/07/002-Ataay.pdf

Bacchus, N. (2005). The effects of globalization on women in developing nations [Unpublished hornors college theses]. Pace University.

Baypınar, M. B., \& Erkut, G. (2011). Ekonomik küreselleşme ve Türkiye'de bölgesel üretkenlik düzeylerinde yakınsama. ITÜ Dergisi/a, 10(1), 61-70. http://itudergi.itu.edu.tr/index.php/itudergisi a/ article/viewFile/1288/1182 
Berberoğlu, N. (1996). Makro ekonomi teorisi. Birlik Ofset.

Cihangir, E., Demirhan, Ö. \& Şeremet, M. (2020). An outlook on woman's status in rural tourism potential: The case of Van herby cheese production. International Journal of Geography and Geography Education (IGGE), 42, 199-222. https://doi. org/10.32003/igge.692207

Çakır, Ö. (2008). Türkiye'de kadının çalışma yaşamından dışlanması. Erciyes Üniversitesi iktisadi ve Idari Bilimler Fakültesi Dergisi, 31, 25-47. https://dergipark.org.tr/en/pub/erciyesiibd/ issue $/ 5888 / 77876$

Dedeoğlu, S. (2000). Toplumsal cinsiyet rolleri açısından Türkiye'de aile ve kadın emeği. Toplum ve Bilim, 86(3), 139-170.

Dedeoğlu, S. (2009). Eşitlik mi ayrımcılık mı? Türkiye'de sosyal devlet, cinsiyet eşitliği politikaları ve kadın istihdamı. Çalışma ve Toplum, 2(21), 41-54. https://calismatoplum.org/Content/pdf/ calisma-toplum-1299-30612c5d.pdf

Demirli, Y. (2015). Türk vergi sisteminde ücret tabanli istihdam teşvikleri: Gelir vergisi stopaji teşviki/desteği ve ücret istisnasi. Uluslararası Yönetim iktisat ve Işsetme Dergisi, 11(25), 141-162. https://doi.org/10.17130/ijmeb.2015.11.25.933

Doğan, B. B., \& Mehmet, K. (2014). TRC2 Bölgesinde kadın istihdamı sorunları ve çözüm önerileri. International Journal of Social and Economic Sciences, 4(2), 91-106.

Doğruel, F., \& Doğruel, A.S. (2003). Türkiye'de bölgesel gelir farklılıkları ve büyüme. İçinde A.H. Köse, F. Şenses \& E. Yeldan (Der.) iktisat üzerine yazılar 1, Küresel düzen: Birikim, devlet ve sınıflar (ss.287-318). Iletişim Yayınları.

Donovan, J. (2015). Feminist Teori: Entelektüel Gelenekler (10. Baskı). iletişim Yayınları.

Durukan, L. (2021). Türkiye'de kadın girişimcilerin desteklenmesinde KOSGEB'in rolü. Gazi iktisat ve işletme Dergisi, 7(1), 17-37. https://doi.org/10.30855/gjeb.2021.7.1.002

Ercan, F. \& Özar, Ş. (2000). Emek piyasası teorileri ve Türkiye'de emek piyasası çalışmalarına eleştirel bir bakış. Toplum ve Bilim, 86(2), 22-71. https://doi.org/10.30798/makuiibf.791419

Erdoğan, S. \& Yaşar, S. (2018). Türkiye'de kadın istihdamının gelişimi: Konya-Karaman örneği. Karamanoğlu Mehmetbey Üniversitesi Sosyal ve Ekonomik Araşttrmalar Dergisi, 20(34), 18-28. https:// dergipark.org.tr/en/pub/kmusekad/issue/38118/439807

Eşiyok, B. A. (2012). Bölgesel kalkınma, yeni bölgecilik ve bölgesel kalkınma. Memleket, Siyaset, Yönetim, 7(17), 240-248. http:// www.msydergi.com/uploads/dergi/57.pdf

Filiztekin, A. (1998). Convergence across industries and provinces in Turkey. Koç Üniversitesi tartışma metni. http://myweb.sabanciuniv.edu/alpayf/files/2010/04/provconv.pdf

Gerşil, G. (2015). Küresel boyutta yoksulluk ve kadın yoksulluğu. Journal of Management \& Economics, 22(1), 159-181. http:// yonetimekonomi.cbu.edu.tr/dergi/pdf/C22S12015/159-181.pdf

Gezici, F. \& Hewings, G. J. (2004). Regional convergence and the economic performance of peripheral areas in Turkey. Review of Urban \& Regional Development Studies, 16(2), 113-132. https:// doi.org/10.1111/j.1467-940X.2004.00082.x

Halaç, U. \& Kuştepeli, Y. (2008). Türkiye'de bölgesel gelirin yakınsaması: Gelir dağılımı açısından bir değerlendirme, Dokuz Eylül Üniversitesi İsletme Fakültesi Discussion Paper Series, 8(1), 1-14. https://core.ac.uk/download/pdf/7059777.pdf

İnce, M. (2010). Kadın Istihdamı ve Kadın Işgücüne Olan Talep Türkiye Örneği [Yayınlanmamış doktora tezi]. Afyon Kocatepe Üniversitesi.
İzmirlioğlu, Ö. (2019). İşverenlere sağlanan sosyal sigorta prim teşviklerinin istihdama etkisi ve uygulamada karşılaşılan sorunlar: Denizli örneği [Yayınlanmamış yüksek lisans tezi]. Pamukkale Üniversitesi.

Kalaycı, Ş. (2018). SPSS uygulamalı çok değişkenli istatistik teknikleri (9.bs). Dinamik Akademi Yayın Dağıtım.

Karabıyık, i. (2012). Türkiye'de çalışma hayatında kadın istihdamı. Marmara Üniversitesi Iktisadi ve Idari Bilimler Dergisi, 32(1), 231 260. https://dergipark.org.tr/en/pub/muiibd/issue/495/4492

Karaca, O. (2018). Türkiye'de bölgesel yakınsamanın 50 yılı: Yeni veri seti ve 1960-2010 dönemi analizi. Sosyoekonomi, 26(35), 207228. DOI: $10.17233 /$ sosyoekonomi.343016

Karahasan, B. C. \& Bilgel, F. (2018). Türkiye'de bölgesel eşitsizlikler: Yakınsama, dağılım ve mekan. N. Engin, E. Aslanoğlu, O. Erdoğan, B. C. Karahasan \& K. Tata (Ed.), Türkiye ekonomisinde kalkınma ve dönüşüm (ss. 341-380). İmge Kitabevi.

Karakuş, H. (2014). Kraliçe arı sendromu-pembe taciz. Akademik Sosyal Araştirmalar Dergisi, 2(1), 334-356. DOI:10.16992/ASOS.101

KEIG (2013). Türkiye'de kadın emeği ve istihdamına yönelik politikalar: Kadın emeği ve politikalarına dair politika faaliyetlerin 12 ilde değerlendirilmesi. Kadın Emeği ve İstihdamı Girişimi. http:// www.keig.org/wp-content/uploads/2016/03/genelge-kitap-keig.pdf

Koca, Ç. (2016). Türkiye'de istihdam teşviklerinin kadın istihdamı üzerindeki etkileri: Nitel bir araştırma [Yayınlanmamış yüksek lisans tezi]. Ankara Yıldırım Beyazıt Üniversitesi.

Koray, M. (2008). Sosyal Politika (3. Baskı). İmge Kitabevi.

McLanahan, S. S., \& Kelly, E. L. (2006). The feminization of poverty. İçinde Handbook of the Sociology of Gender (ss. 127-145).

Mutluer, M. (1999). Türkiye'de bölgesel dengesizlikler ve bölge planlama çalışmaları üzerine gözlemler. Ege Coğrafya Dergisi, 10, 173-194. https://dergipark.org.tr/en/download/article-fi$\underline{\text { le/56823 }}$

Nas, Ş. \& Değirmen, S. (2018). Türkiye'de bölgelerarası ekonomik eşitsizlikler bağlamında yakınsama sorunsalı. İçinde $Y$. Bayar (Ed.), 4 th SCF International Conference on Economics and Social Impacts of Globalization and Future Turkey-EU Relations (ss. 139-157).

Omay, U. (2011). Yedek işgücü ordusu olarak kadınlar. Çalışma ve Toplum, 3, 137-165. https://calismatoplum.org/Content/pdf/ calisma-toplum-1378-f7d693b9.pdf

Önder, N. (2013). Türkiye'de kadın işgücünün görünümü. Çalışma Dünyası Dergisi, 1(1), 35-61.

Özbay, F. (2019). Kadın emeği seçme yazılar. İletişim Yayınları.

Özaslan, M. (2006). Türkiye'de ekonomik ve sosyal boyutlarıyla bölgesel gelişmişlik farklılıkları. icçinde A. Özçağlar (Ed.), IV. Ulusal Coğrafya Sempozyumu Bildiriler Kitabı (ss.179-201).

Özdemir, Z., Yalman, G. \& Bayrakdar, S. (2012). Kadın istihdamı ve ekonomik kalkınma: Geçiş ekonomileri örneği. İçinde S. Sarı, A. H. Gencer, B. Aşık, \& A. Turdalieva (Ed.), International Conference on Eurasian Economies Bildiri Kitabı (ss.115-122).

Öztürk, S. \& Başar, D. (2018). Türkiye'de kadınların işgücü piyasasına yönelik tercihleri: Kayıt dışı sektör özelinde bir analiz. Sosyal Güvenlik Dergisi, 8(2), 41-58. https://doi.org/10.32331/sgd.492887

Peker, A. E. \& Kubar, Y. (2012). Türkiye'de kırsal kesimde kadın istihdamına genel bir bakış. Afyon Kocatepe Üniversitesi Iktisadi ve Idari Bilimler Fakültesi Dergisi, 14(2), 173-188. https://dergipark.org.tr/tr/pub/akuiibfd/issue/1620/20304 
Rutkowski, J. (2006). Labor market developments during economic transition (Working Paper No: 3894). The World Bank.

Serel, H. \& Özdemir, B. S. (2017). Türkiye'de kadın istihdamı ve ekonomik büyüme ilişkisi. Yönetim ve Ekonomi Araştırmaları Dergisi, 15(3), 134-150. : http://dx.doi.org/10.11611/yead.310569

Sevinç, H., Bozkurt, E. \& Sevinç, D. E. (2016). Ekonomik büyümede kadın istihdamının rolü? Yakınsama temelli kanıtlar. Cumhuriyet Üniversitesi iktisadi ve Idari Bilimler Dergisi, 17(1), 57-69. https://dergipark.org.tr/en/pub/cumuiibf/issue/28001/297315

Takım, A. \& Ersundur, M. (2018). Türkiye'de teşvik sisteminin yapısı, sorunları ve etkinliği üzerine bir politika önerisi: Tek bir uygulamacı kuruluş sorunları çözer mi? Atatürk Üniversitesi iktisadi ve Idari Bilimler Dergisi, 32(3), 725-744. https://dergipark.org.tr/ en/pub/atauniiibd/issue/38242/412748

Taşçı, H. M., \& Darıcı, B. (2010). Türkiye'de eksik istihdamın belirleyenleri HIA ile bir mikro veri uygulaması. Maliye Dergisi, 158, 278-300. https://ms.hmb.gov.tr/uploads/2019/09/13-1.pdf

TÜSIAD. (2008). Türkiye'de bölgesel farklar ve politikalar (Yayın No. TÜSIAD-T/2008-09/471). Türkiye Sanayici ve İşadamları Derneği. https://tusiad.org/tr/vayinlar/raporlar/item/4237-turkiyede-bolgesel-farklar-ve-politikalar

TÜiK (2021). İşgücü istatistikleri. https://data.tuik.gov.tr/Bulten/Index? $\mathrm{p}=$ Isgucu-Istatistikleri-Ocak-2021-37486

Walby, S. (2021). Patriyarka kuramı (2. Baskı). Dipnot Yayınları.

Yavan, N. (2011). Yeni yatırım teşvik sisteminin bölgesel kalkınma politikaları çerçevesinde değerlendirilmesi. İçinde $E$. Dedeoğlu, A. Eraydın S. Sertesen, E. Demir, E. Koyuncu, E. Çağlar, T. Köroğlu, U. Şahbaz., \& Ü. Şener (Edt.), TEPAV 5. Bölgesel Kalkınma ve Yönetişim Sempozyumu Sanayi Politikasının Yönetişimi Bildiri Kitabı (ss.127-154).

Yavan, N. (2012). Türkiye'de yatırım teşviklerinin bölgesel belirleyicileri: Mekânsal ve istatistiksel bir analiz. Coğrafi Bilimler Dergisi, 10(1), 9-37. https://doi.org/10.1501/Cogbil 0000000129

Yumuş, A. (2011). Kalkınma planları çerçevesinde toplumsal cinsiyet eşitliği anlayışının ekonomik, toplumsal ve siyasal boyutları [Yayınlanmış uzmanlık tezi]. Başbakanlık Kadının Statüsü Genel Müdürlüğü .

Yüceşahin, M. M. (2016). Toplumsal cinsiyet ve mekanın karşılıklı ilişkisi: Patriyarkanın sosyal mekanı örgütleyişine dair bir tartışma. Kadın/Woman 2000, 17 (1), 73-101. https://doi.org/10.33831/ iws.v17i1.70 